\title{
BAFfling pathologies: alterations of BAF complexes in cancer
}

\section{Authors}

Ophelie Arnaud ${ }^{1}$, François Le Loarer ${ }^{2}$ and Franck Tirode ${ }^{1,3}$

\section{$\underline{\text { Affiliations }}$}

1. Univ Lyon, Université Claude Bernard Lyon 1, INSERM 1052, CNRS 5286, Cancer Research Center of Lyon, Centre Léon Bérard, F-69008, Lyon, France

2. Institut Bergonié, Department of Pathology, F-33000 Bordeaux, France

3. Department of translational research and innovation, Centre Léon Bérard, F-69008, Lyon, France

\section{Corresponding author}

Franck Tirode, $\mathrm{PhD}$.

Cancer Research Center of Lyon, INSERM U1052

Centre Léon Bérard, 28 Rue Laënnec, 69373 Lyon Cedex 08

Tel.: +33469856145

Email: franck.tirode@1yon.unicancer.fr 


\section{$\underline{\text { Abstract }}$}

To activate or repress specific genes, chromatin is constantly modified by chromatinremodeling complexes. Among these complexes, the SWItch/Sucrose Non-Fermenting (SWI/SNF) complex, also referred to as BRG1-Associated Factor (BAF) complex, moves the nucleosome along chromatin using energy provided by ATP hydrolysis. In mammalian organisms, the SWI/SNF complex is composed of 10-15 subunits, depending on cell type, and a defect in one of these subunits can have dramatic consequences. In this review we will focus on the alterations identified in the SWI/SNF (BAF) complex subunits that lead to cancerous pathologies. While SMARCB1 was the first mutated subunit to be reported in a majority of malignant rhabdoid tumors, the advent of next-generation sequencing allowed the discovery of mutations in various SWI/SNF subunits within a broad spectrum of cancers. In most cases, the mutation leads to a loss of expression or to a truncated subunit unable to perform its function. Even though it is now commonly acknowledged that approximately $20 \%$ of all cancers present a mutation in a SWI/SNF subunit, some cancers are associated to a specific alteration of a SWI/SNF subunit, which acts either as tumor suppressor genes or as oncogenes, and therefore constitute diagnostic or prognostic biomarkers. Consistently, therapeutic strategies targeting SWI/SNF subunits or the genes affected downstream have been revealed to treat cancers.

\section{Keywords}

SWI/SNF complex, BAF complex, Chromatin Assembly and Disassembly, SWI/SNF-deficient pathology, BAF-deficient pathology 


\section{Main text}

\section{A. Overview}

DNA, which measures approximately two meters in length within each cell, is compacted into chromatin in the nucleus. This highly compacted chromatin must be relaxed for subsequent replication, repair or transcription. The structure of chromatin is reorganized by histone modification enzymes (by acetylation or methylation) or ATP-dependent nucleosome remodelers, which move nucleosomes along DNA using energy derived from ATP hydrolysis. Among the ATP-dependent remodelers, SWI/SNF (BAF) complexes have been the most extensively studied. SWI/SNF have between 5,000 - 10,000 binding sites over the entire genome [1] and thus affect many genes and pathways, including neuronal development [1] or hormone signaling [2]. Because of their key roles in the regulation of gene expression, alterations in SWI/SNF complexes impact diverse cellular functions directly linked to cancers. SMARCB1 was the first cancer-associated subunit to be unveiled in malignant rhabdoid tumors (MRTs) [3], prior to the discovery by next-generation sequencing of other SWI/SNF mutated subunits in a wide array of cancers. Eventually, the mutation rate of SWI/SNF subunits is almost equivalent to that of TP53, the single-most mutated gene in cancer (19\% and 26\%, respectively) $[4,5]$. As described in Table 1, some of the SWI/SNF subunits are more frequently mutated than others. These mutations, which can be either heterozygous or homozygous and present in somatic and/or germline cells, often lead to the loss-of-expression or to a truncated, nonfunctional protein. Additionally, most SWI/SNF mutations are present at low frequencies and are distributed across gene coding sequences, with no apparent site preference $[4,6]$. However, while this is true for most cancers harboring mutations in SWI/SNF subunits, there is few cancers in which the SWI/SNF alteration is pathognomonic and defined as the "driver" of tumorigenesis. This includes MRT and AT/RT, Small Cell Carcinoma of the Ovary (SCCOHT), Synovial sarcomas or SMARCA4-Deficient Thoracic Sarcomas (SMARCA4-DTS). In this 
review of the vast and increasing literature depicting the role of SWI/SNF in cancers, we will explore subunit by subunit the alterations of SWI/SNF that are thought to lead to oncogenesis and describe their associated tumor types. But before, we need to expose the anatomy of the SWI/SNF complexes.

\section{B. The SWI/SNF complexes}

The saga of the SWI/SNF complexes discovery originated in 1984 by the concomitant identification in Saccharomyces cerevisiae of six new genes involved in mating-type switching, namely, $H O$ and SWI 1-5 [7] and five new genes (SNF 2-6) involved in sucrose fermentation [8]. But it was 8 years later that a study from Peterson and Herskowitz demonstrated that some SWI and SNF genes were similar and that some of them were bound together in a complex that modulates the expression of genes and named SWI/SNF [9]. The subsequent depiction of this complex in other species demonstrated that it is evolutionarily conserved from yeast to human $[10,11]$, although it is mainly a transcription activator in yeast $[12,13]$ whereas it activates or represses gene transcription in mammals [14]. Also, the mammalian SWI/SNF complexes comprise 10-15 subunits among the 29 subunits characterized thus far, a number and variety of subunits much larger than in yeast (Figure 1A) $[5,10]$. The composition of these mammalian complexes was first unraveled in 1996 through the initial purification of 12 proteins that coimmunoprecipitated together with BRG1 (therefore called BRG1-Associated Factors or BAF) [15] and still continues to be enriched as demonstrated by the recent identification through a proteomic screen of additional subunits, including BCL7A/B/C, BCL11A/B, BRD9 and SS18 (SYT) [5]. Amongst all the subunits described, only two subunits possess a catalytic activity. These are two mutually exclusive catalytic ATP-dependent helicases, named Brahma (BRM) and Brahma-related gene 1 (BRG-1), encoded by SMARCA2 and SMARCA4, respectively. These two subunits contain 6 conserved domains: a QLQ domain, a proline-rich domain, a small helicase/SANT-associated domain, a DNA-dependent ATPase domain, a retinoblastoma 
(RB)-binding domain (LxCxE) and a Bromo domain (Figure 1B). The Bromo domain interacts with the acetylated histone and participates in the binding and the stability of the SWI/SNF complex onto the DNA [16]. The LxCxE domain binds to members of the RB tumor suppressor family [17], while the QLQ domain is implicated in protein-protein interactions. Finally, the helicase and DExDc domains separate DNA double strands [18], a catalytic activity that requires ATP hydrolysis. The presence of one of these two subunits is mandatory for the ATPdependent functions of the complex [19-21]. SWI/SNF complexes also contain a set of core subunits required for nucleosome mobility, namely, BAF155 (SMARCC1), BAF170 (SMARCC2) and BAF47 (SMARCB1). Adding to these subunits, the SWI/SNF complexes present 7-10 accessory subunits involved in the targeting of specific loci and thus responsible for the relative specific set of genes targeted by the different complexes [7-10] (Figure 1A). Eventually, each subunit contains specific domains (bromodomains, chromodomains, DNAbinding domains, ARID, Zing finger, etc.) required for the interaction with DNA or histones and essential for the remodeling activities of the complex (for recent reviews see [10,22,23]).

The mammalian complexes are composed of precise sets of subunits, yielding a great diversity of SWI/SNF complexes, which in vertebrates are divided into 2 sub-classes: The BRG/hBRM-associated factors (BAF) complexes that specifically contain BAF250A/B, BAF45D and SS18subunits and the Polybromo-associated BAF (PBAF) complexes that exclusively contain BAF200, BAF180, BAF45A, BRD7 and only one of the ATPases, SMARCA4 [15,24,25] (Table 2). Taking into account variations of the accessory subunits, Wu and collaborators estimated that hundreds of versions of SWI/SNF complexes may exist $[15,26]$. This diversity is essential to the differentiation during embryogenesis and development. Studies performed in mice [27-38], Caenorhabditis elegans [39] or Xenopus $[40,41]$ showed striking evidence of the effect of modifications in the composition of SWI/SNF complexes in neural development, from embryonic stem (ES) cells to post-mitotic neurons 
(Table 2 and [1] for a recent review). A switch in SWI/SNF subunits also affects several other cell fate decisions, such as the skeletal, cardiac muscle and hematopoietic differentiations $[10,42-46]$.

The variety of SWI/SNF complexes allows for their specialization in modulating specific gene expression. Therefore, depending on the cellular background, SWI/SNF complexes have been implicated in a variety of physiological roles, such as the regulation of hormonal pathways and their crosstalk [2,47], hepatic lipid metabolism [48] or the regulation of cell cycle progression. Although SWI/SNF and polycomb complexes are functional antagonists [49,50], the mechanisms underlying SWI/SNF complex activities remain poorly understood. Two recent studies shed new light on these mechanisms in both physiological and pathological contexts. The first study characterized the role of SWI/SNF complexes in the regulation of lineagespecific enhancers [51]. Alver and co-workers revealed that SWI/SNF complexes directly bind to p300 histone acetyltransferase and thus regulate the active H3K27Ac mark on the targeted genes. Interestingly, this SWI/SNF regulation is less present in super-enhancer or transcribed regions but displays strong activity in typical distal enhancers with enrichment in the genes involved in differentiation and development. This study led to the hypothesis that the loss of SWI/SNF subunits induces tumorigenesis by acting on the acetylation of the typical enhancers of genes implicated in differentiation and development. The second study characterized the opposing functions of SWI/SNF and polycomb complexes [52]. Although the specific antagonism between SMARCB1 from SWI/SNF complexes and EZH2 from the polycomb repressive complex 2 (PRC2) was known [50], the precise mechanism was not yet characterized. Using an inducible system allowing for targeting SWI/SNF onto a precise promoter, Kadoch and co-workers demonstrated that the SWI/SNF complex rapidly removes both PRC1 and PRC2 complexes from their chromatin binding sites, consequently increasing the chromatin accessibility for transcriptional factors at these sites [52]. These studies were 
particularly informative about the role of SWI/SNF under physiological conditions and provided an explanation for SWI/SNF complex deficiency in some cancers, such as SMARCA4-DTS, MRT or synovial sarcoma, as we will see in the next section.

\section{SWI/SNF complex alterations in cancer}

SWI/SNF complexes can be altered in a number of different ways in a number of different cancerous pathologies. In this section, we will review the principal subunits, how they are altered and in which cancers they are involved.

\section{$\underline{\text { Loss of SMARCB1 (BAF47) activity in various cancers }}$}

SMARCB1 encodes the ubiquitously expressed nuclear protein BAF47 (or Snf5). SMARCB1 is instrumental in epigenetic regulation and cell cycle progression and has been implicated in several signaling pathways, including the regulation of oncogenes [53-58]. SMARCB1 is one of the most potent tumor suppressor genes [55,57,58], and its loss-of-function has been described in several tumors (Table 1).

The first implication of SMARCB1 in cancer was reported in 1998, in MRTs, in which this gene is incapacitated in virtually all cases either by genomic deletions or truncating mutations [3]. Subsequently, using whole-exome sequencing, Lee and co-workers demonstrated that the bi-allelic loss-of-function of SMARCB1 is the only recurrent genetic events occurring in MRT diseases [59], which was further confirmed by the very low mutational burden observed in these tumors [60]. MRT is a rare and extremely aggressive cancer of early childhood (typically diagnosed under the age of 2 years, although it may occur at any age), and it is frequently metastatic. Consequently, prognosis is poor with a mortality rate of $80 \%$ within the first year [61]. MRTs have three privileged locations, the central nervous system (tumors are then referred to as atypical teratoid/rhabdoid tumor or AT/RT) [62], the kidneys (also called rhabdoid tumor of the kidney or RTK) [63] and soft tissue (sometimes referred in this site as 
MRT) [64], although any site can be affected [65,66]. Pathologically, MRTs are composed of sheets of undifferentiated round to epithelioid tumor cells that display monomorphic vesicular nuclei. MRTs have high-grade features with extensive necrosis and high mitotic activity. Typically, tumor cells display so-called "rhabdoid features", defined as paranuclear eosinophilic inclusions, a feature which was initially considered to represent rhabdomyoblastic differentiation [67]. However, rhabdoid features are primarily focal and are not pathognomonic of MRT.

The functional impact of SMARCBI deficiency in these tumors was initially unraveled in 2008, when Kia and colleagues demonstrated that re-expression of SMARCB1 in MRT cells led to the re-expression of CDKN2A via a PRC2 complex-mediated loss of DNA methylation at its locus [68]. In 2010, Wilson and co-workers broadened this observation by demonstrating that the loss of SMARCB1 increases the abundance of the PRC2 subunit EZH2, enforcing repression of its targets [69]. Hence, in MRTs, , the SMARCB1-deficient SWI/SNF complexes, which induces higher EZH2 expression, can no longer unbind PRC2 complexes resulting in the repression of the CDKN2A tumor suppressor gene and consequently in an increase of proliferation [52]. Finally, looking at a more genome wide effect, the group of Kadoch very recently demonstrated that the re-expression of SMARCB1 in MRT cells had a profound impact on increasing BAF and PBAF occupancy on enhancers and bivalent promoters, respectively [70].

Loss of SMARCB1 most often results from somatic inactivation but is occasionally associated with germline mutations (for a recent review [22]). In the rhabdoid predisposition syndrome type 1 (OMIM\#609322), carriers of germline SMARCB1 alterations are mainly prone to the development of MRTs, although chondrosarcomas have also been reported $[54,71,72]$. Germline mutations of SMARCBI also predispose to multiple schwannomas and meningioma in the context of familial schwannomatosis syndrome [73,74]. Affected patients develop tumors 
in the spinal, peripheral or cranial nerves, which are benign but may still induce neurological complications [75]. SMARCB1 mutations account for half of all reported familial schwannomatosis cases. In these cases, mutations are mostly located in exon $1[76,77]$ and SMARCB1 typically conserves its ability to control the cell cycle, accounting for the less aggressive phenotype of tumors developed in this setting [78].

In addition to MRTs, SMARCB1 plays also a critical role in epithelioid sarcoma (EPSR), presenting mutation rates exceeding 80-90\% [79-83]. In 1994 Cordoba and co-workers highlighted the implication of chromosome 22 in EPSR with the characterization of a $\mathrm{t}(8 ; 22)(\mathrm{q} 22 ; \mathrm{q} 11)$ translocation, but rather connected it to the Ewing sarcoma translocated region on chromosome 22q11 [84]. Several groups subsequently documented a loss of SMARCB1 expression in EPSR mostly resulting from homozygous deletions of the gene $[79,82,85]$. EPSR is an indolent tumor with a high rate of recurrence and metastasis. This condition predominantly affects young adults and invades the soft tissue. Originally described as restricted to distal extremities, EPSR has now been reported in several anatomical regions [67]. Depending on the localization of the tumors, 2 types of EPSR have been described: the conventional-type, mostly located in the fingers, hands, forearms or feet and the proximal-type occurring in the upper extremities as well as in the pelvis, vulva, penis or spine [86]. Moreover, histopathological differences discriminate these two subtypes, since conventional EPSR presents plump epithelioid and spindled cells with a multinodular proliferation and typically a single and central nucleolus [87], whereas proximal EPSR is characterized by large cells with an epithelioid cytomorphology and frequent rhabdoid cytoplasmic inclusions [86].

More recently, SMARCB1 truncations following unbalanced translocations were described in renal medullary carcinoma (RMC) $[88,89,90]$. RMC is a rare and highly aggressive carcinoma primarily affecting young men with sickle cell traits. The prognosis is poor with a survival period of several months, partly due to the late diagnosis of the pathology, often 
associated with metastasis [91-94]. Tumors cells originating from the renal medulla have a highly atypical nucleus and dense eosinophilic cytoplasm that may contain rhabdoid inclusions $[67,88]$. During diagnosis, the loss of SMARCB1 is used to discriminate RMC from collecting duct carcinoma (CDC) [88]. Despite the few RMC cases studied, SMARCB1 loss-of-function is thought to induce cyclin D1 that leads to a progression through the G1 phase of the cell cycle and to cellular proliferation. This hypothesis relies on the observation that cyclin D1 is expressed in the nucleus of neoplastic cells [88].

To date, the last tumor type described in the literature as harboring a loss of SMARCB1 is a subtype of sinonasal carcinoma [95-97]. Sinonasal carcinomas represent 5\% of head and neck carcinomas, affecting patients in their fifth decade and are associated with a 5-year survival rate of approximately 50\% [98]. SMARCB1-deficient sinonasal carcinoma, underlined by SMARCB1 deletions, represents approximately $10 \%$ of sinonasal carcinomas [99]. As in MRT, their genome seems to be highly stable as demonstrated in the only case assessed by next-generation sequencing [100], suggesting that loss of SMARCB1 is likely the driving event of tumorigenesis. This cancer is an aggressive malignancy with a median survival time of 15 months, as patients often present an advanced T4 tumor stage at diagnosis. These poorly differentiated/undifferentiated tumors may nevertheless display a basaloid phenotype or focal rhabdoid features (for a review, see [97]).

Finally, poorly differentiated pediatric chordomas displaying a common loss of SMARCB1 underlined by chromosome 22q11 deletions have been described [101]. SMARCB1deficient chordomas occur only in pediatric patients, displaying methylome profiles distinct from those of conventional chordomas and from MRT patients [104].

Displacement of SS18 in synovial sarcoma 
SS18 is the last characterized SWI/SNF subunit to date. Using a proteomic approach, Kadoch and Crabtree identified SS18 as a new core subunit of the BAF complex [102]. SS18 (formerly known as SYT) was first identified in synovial sarcoma (SS) in which the translocation $\mathrm{t}(\mathrm{X} ; 18)(\mathrm{p} 11.2 ; \mathrm{q} 11.2)$ provoked the fusion of SS18 on chromosome 18 to SSX1, SSX2 or SSX4 on the X chromosome [103]. This chromosomal translocation results in the fusion of the SS18 C-terminus to the 78 C-terminal amino acids of the SSX protein. Kadoch and Crabtree elegantly demonstrated that the SS18-SSX fusion protein competes with the normal SS18 subunit for incorporation into the SWI/SNF complex. As a result, and likely owing to the larger size of the fusion protein, the BAF47 subunit is expulsed from the synovial sarcoma BAF (ssBAF) complex. The eviction and subsequent degradation of BAF47 should result in a loss-of-function, as seen in MRTs. However the authors demonstrated that SS18-SSX incorporation within the SWI/SNF complex leads to a gain-of-function of the complex, with enhanced chromatin occupancy and the robust eviction of the PRC. The ssBAF is indeed redirected towards different genomic loci, probably triggered by the SSX moiety of the fusion protein that binds DNA at specific sites [104]. The ssBAF complex can thus bind to and activate the SOX2 oncogene [52,102]. To date, this example is the only evidence of the acquired oncogenic properties of the SWI/SNF complex as opposed to its predominant role as a tumor suppressor. Synovial sarcoma is a rare soft tissue sarcoma affecting young adults (mean age of 32 years) that may locate in any anatomical site but with a preference for extremities, head and neck as well as the abdominal wall. Prognosis is poor with a 5-year survival rate of $50-80 \%$ [105]. There are two major subtypes of synovial sarcoma, the biphasic and the monophasic spindle cell types, along with less frequent subtypes presenting morphological and immunohistochemical heterogeneity.

\section{$\underline{\text { Loss-of-function of catalytic subunits (BRG-1 and BRM) in cancer }}$}


SMARCA2 and SMARCA4 encode the 2 mutually exclusive ATPase subunits of the complex, BRM and BRG-1, respectively. While SMARCA2 mutations are primarily implicated in neurological disorders rather than in cancers [10], SMARCA4 is considered a tumor suppressor [106]. Mutations in SMARCA4 are recurrent in 2 types of cancers: the small cell cancer of the ovary hypercalcemic type (SCCOHT) [107] and SMARCA4-deficient thoracic sarcomas (SMARCA4-DTS) [108].

SCCOHT is a rare aggressive type of ovarian cancer predominantly affecting young women [109]. Most tumors are composed of round poorly differentiated cells arranged in sheets and microcystic areas. Half of the cases contain larger tumor cells with vesicular nuclei dotted with conspicuous nucleoli, also known as "large cell" variants, with features reminiscent of MRT [109]. Focal cytoplasmic rhabdoid features may also be observed [109]. These tumors are characterized by biallelic SMARCA4 inactivating mutations (including truncation, frameshift or deletion) often targeting the helicase catalytic domain and leading to the loss of expression of the protein $[107,110,111]$. Furthermore, in nearly half the cases of SCOOHT, SMARCA4 mutations have been identified in germline cells and may occur in the context of rhabdoid tumor predisposition syndrome 2 (OMIM\# 613325) [107,112].

SMARCA4-DTS are associated with recurrent SMARCA4 mutations leading to a BRG1 loss of function [108,113]. Concomitantly, mutations of TP53 are observed in $2 / 3^{\text {rd }}$ of cases. These tumors, composed of sheets of round to epithelioid cells harboring vesicular nuclei, display high-grade features with extensive necrosis and hemorrhage. This malignancy, primarily occurring in young males with a smoking habit, is extremely aggressive with limited response to chemotherapy and a rapid local progression, leading to a poor prognosis, with a median survival time of 7 months..

Beside these two tumor types, in which a SMARCA4 loss of function is observed in $100 \%$ of cases, SMARCA4 is also mutated in a broad range of cancers with varying frequencies, 
including Burkitt's lymphomas [114], lung adenocarcinomas [115-117] or esophageal adenocarcinomas [118] (see Table 1), with the majority of the mutations targeting the helicase catalytic domain. In these tumors, knowing how SMARCA4 mutations are contributing to the oncogenesis is still to be investigated.

SMARCA2 is rarely mutated in human cancers, except in adenoid cystic carcinoma (ACC) [119]. ACC primarily originates from the salivary glands but can also be found in several other anatomical sites, including the breasts, lacrimal glands, lungs, brain, trachea, and paranasal sinuses. ACC is of poor prognosis due to a high metastatic rate [119]. The tumor is typically composed of ductal and myoepithelial cells with a cribriform pattern. Using wholegenome and exome sequencing of $60 \mathrm{ACC}$ patients, Ho and co-workers showed that SMARCA2 is the most frequently mutated gene and $35 \%$ of the identified mutations were found in SWI/SNF subunit genes. However, the role of SMARCA2 mutations in ACC tumorigenesis needs to be further addressed, as ACC is characterized by recurrent gene fusions involving the $M Y B$ and/or MYBL1 oncogenes considered as the driver events of these tumors [120].

Lastly, mutations in the catalytic subunits may also be found in poorly differentiated carcinomas of the gastrointestinal tract including: colon, small bowel, stomach and distal esophagus. These carcinomas comprise glandular areas together with poorly differentiated solid areas in which tumor cells may have rhabdoid features [95,121]. These undifferentiated gastrointestinal carcinomas (UGC) mostly display SMARCB1 or SMARCA4 inactivation although SMARCA2 and ARIDIA alterations have also been reported. Interestingly, the undifferentiated component displays rhabdoid features, providing a link between rhabdoid morphological features and SWI/SNF deregulation. SWI/SNF alterations in these tumors represent secondary genetic events acquired at a late stage of tumorigenesis. SMARCA2 and SMARCB1 are the most frequent SWI/SNF mutated subunits in UGC (77\% and $50 \%$ of the cases, respectively). While all cases presenting a SMARCB1 mutation also harbor a mutation in 
the SMARCA2 subunit, mutations affecting SMARCA2 and SMARCA4 are mutually exclusive, and the same is true for SMARCB1 and SMARCA4 [121]. Notably, these 4 SWI/SNF subunits are the only subunits tested for mutations in these cancers.

In keeping with BRG-1 and BRM being the mandatory catalytic, mutually exclusive, subunits of SWI/SNF, the team of Charles Roberts demonstrated that in SMARCA4-deficient tumor cells, SMARCA2 was up-regulated and my therefore complement the loss of BRG1 within SWI/SNF complexes [122]. Targeting BRM in SMARCA4-deficient tumors thus represent an interesting therapeutic approach [123-125]. Nevertheless, we and others observed that SCCOHT and SMARCA4-DTS cells presented an intriguing common feature: the concomitant loss of SMARCA4 and SMARCA2 expression, the later not being supported by any gene alteration $[108,123,126]$. Moreover, treatment of SCCOHT cells with the histone deacetylase (HDAC) inhibitor trichostatin A restores the expression of SMARCA2, suggesting a mechanism of epigenetic silencing of SMARCA2 or an indirect inhibitory effect on SMARCA2 mRNA degradation [123]. Unlike the synthetic lethality observed in other SMARCA4-deficeint tumors, in SCCOHT the re-expression of SMARCA2 abolishes cell proliferation.

Despite different clinical settings, MRT, SCCOHT and SMARCA4-DTS tumors harbor similar features: MRTs and SCCOHTs present very simple genome and epigenome (SMARCA4-DTS tumor genome is rather complex), SCCOHTs and SMARCA4-DTS share the common loss of SMARCA2 expression, all these tumors present somehow rhabdoid features and clustering analyses demonstrated that expression profiles of these three tumor types are quite correlated $[108,112,127,128]$. The deregulation of genes involved in embryonic stem cell transcriptional program, such as SOX2 that is upregulated in both AT/RTs [129] and SMARCA4-DTS [108], is a common trait of these tumors. In keeping with the inability of an ATPase-lacking SWI/SNF to displace PRC complexes from the chromatin [52], the repression 
of lineage specific genes might be the results of the persistence of PRC2 at these loci.. This hypothesis is supported by the demonstration that EZH2 inhibition abolishes proliferation of both SCCOHT and MRT cells [130].

\section{Involvement of the SWI/SNF accessory subunits in cancer}

SWI/SNF accessory subunits are of tremendous importance for conferring the specificity of a given complex in a given tissue or cell. Disease-causing mutations are therefore also found in some accessory SWI/SNF subunits. Among these subunits, SMARCE1 was found mutated in $100 \%$ of familial multiple spinal meningioma cases [131-133], leading to the consideration of this gene as a tumor suppressor. Meningiomas are slowly developing tumors with a cranial or spinal localization. Loss of SMARCE1 (BAF57) only occurs in the spinal form and is associated with a clear-cell histological morphology [131]. This clear subtype is more aggressive and has a tendency to spread to the CNS where it forms metastases [133]. Notably, the development of the disease occurs earlier in men (between 2 and 10 years of age) than in women (between 14 and 30 years of age). Although the underlying reason remains unknown, a hormonal role has been suggested in the growth of meningioma [132], consistent with the role of SMARCE1 in steroid hormone responses [47].

BAF250a plays a critical role in tumorigenesis. Its encoding gene, ARIDIA, is one of the most commonly affected SWI/SNF genes in human cancers. ARIDIA is mutated in a wide variety of neoplasms, such as hepatocellular carcinoma [134,135], lung adenocarcinoma [117], gastric cancers [136-138], bladder cancers [139,140] or cholangiocarcinomas [141] (Table 1). More importantly, ARIDIA is considered a tumor suppressor gene in ovarian clear cell carcinomas (OCCC) [142] in which this gene is mutated in half of the cases [6,142]. OCCC is an aggressive form of ovarian cancer with a poor prognosis and a resistance to standard 
platinum-based chemotherapy [143-145]. OCCC are composed of hobnail cells with a clear cytoplasm. Similar to observations in ovarian cancer, mutations in ARID1A occur more frequently in endometrial clear cell tumor subtypes than in the serous subtype [146]. Accordingly, ARIDIA is mutated in almost $40 \%$ of endometrial cancers, and even if the mechanism is not yet clear, the ARIDIA mutation has been linked to the progression of benign endometriosis to carcinoma [6]. Remarkably, ARID1B, encoding the BAF250b subunit that is mutually exclusive with BAF250a, is rarely mutated in cancer, except in childhood neuroblastoma [147].

SMARCC2 is scarcely mutated in cancers (Table 1), except in gastric and colorectal cancers, in the context of microsatellite instability [148]. Kim and co-workers observed a repeat sequence in exon 8 of $S M A R C C 2$, which is a hotspot for frameshift mutations, present in $9 \%$ and $15 \%$ of gastric and colorectal cancers, respectively. This mutation leads to a codon stop and thus a loss-of-function of SMARCC2 (BAF170). However, the role of this mutation in these cancers has not yet been fully determined, and further studies are needed.

\section{$\underline{\text { SWI/SNF cancerous pathologies without genomic or epigenetic alterations of SWI/SNF }}$}

SWI/SNF subunits have also been implicated in tumorigenesis, without harboring alterations in their coding sequence, particularly when a subunit is targeted by epigenetic silencing (as described for instance with SMARCA2 silencing in SCCOHT and SMARCA4DTS). Unaltered SWI/SNF complexes have also been involved in tumorigenesis via their interactions with long non-coding RNAs (lncRNA). Two mechanisms have been described for a lncRNA to perturb SWI/SNF activities: the lncRNA can either directly interacts with the SWI/SNF complex, antagonizing its activities, or force the recruitment of the SWI/SNF complex at some specific loci [23]. In prostate cancer, the overexpressed SChLAP1 lncRNA 
interacts with SMARCB1 [149] and consequently diverts SWI/SNF from some of its target genes, leading to tumor cell invasion and to the promotion of metastasis $[149,150]$. In contrast, in hepatocellular carcinomas, the $\operatorname{lncTCF} 7$ lncRNA recruits the SWI/SNF complex to the promoter of the TCF7 gene, increasing TCF7 expression and leading to the activation of the WNT signaling pathway and promotion of tumor progression [151].

SWI/SNF complexes interact with numerous cofactors at specific loci [152]. Hence, based on the same interacting/recruiting models than with the IncRNA, it may be possible that alterations of specific cofactors could lead to the deregulation of the SWI/SNF complexes. We may therefore underestimate the number of cancers presenting a SWI/SNF functional alteration.

\section{Targeting SWI/SNF activities in clinical applications}

Based on next-generation sequencing studies, deregulation of SWI/SNF subunits in tumorigenesis is increasingly demonstrated in a much wider array of cancers than previously thought, impacting diagnosis, as well as therapeutic and prognostic markers in these cancers. With regards to diagnosis, inactivating mutations of core subunits lead to the loss of expression of corresponding subunits which are used to confirm the histopathological diagnosis of tumors underlined by recurrent SWI/SNF alterations, such as MRT, epithelioid sarcomas, SCCOHT and SMARCA4-DTS, to name but a few. In the case of prognosis, SMARCE1 has been proposed as a key pro-metastatic factor in prostate cancer, with high expression levels of SMARCE1 associated with a dramatic increase in the migratory capacity of tumor cells in vitro and in vivo [153]. Similarly, SMARCE1 is a marker of poor prognosis in endometrial carcinomas [154].

Several therapeutic strategies have been devised to exploit the vulnerability of tumor cells harboring SWI/SNF deregulation. First, due to the functional antagonism between SWI/SNF complexes and PRC2, SMARCB1-deficient MRT and SMARCA4-deficient SCCOHT present 
an increase in PRC2 activity $[69,155]$, which can be inhibited with specific inhibitors targeting EZH2, the catalytic subunit of PRC2 responsible for the methylation of lysine 27 of histone $\mathrm{H} 3$. EZH2 inhibition potently arrests rhabdoid tumor growth both in vitro and in vivo $[69,155]$. Phase 2 clinical trials are ongoing to determine whether these findings are applicable in human patients. Interestingly, EZH2 inhibitors may act in synergy with etoposide, a topoisomerase II (Topo II) inhibitor, in a subset of SMARCA4-deficient neoplasms [156]. This synergistic activity may be related to the physical interaction of SWI/SNF complexes with Topo II during the cell cycle [157]. Indeed, upon Topo II inhibition in SMARCA4-wild type cell lines in vitro, SMARCA4 transcript levels increase to compensate for a decrease in Topo II activity [156]. The authors speculated that this compensatory mechanism is abrogated in the case of SMARCA4 mutations, thereby accounting for the synergistic effect of their combination. Moreover, SMARCB1 inactivation leads to cyclin D1 upregulation both in vitro and in vivo $[158,159]$. Thus, phase 1/2 clinical trials are currently ongoing with ribociclib (LEE011), a cyclindependent kinase (CDK) 4/6 inhibitor [160]. Finally, in the context of SMARCA4 inactivation, tumor cell survival relies on the activity of SMARCA2, the alternative ATPase of SWI/SNF complexes. Inhibition strategies targeting SMARCA2 have been demonstrated as successful synthetic lethal strategies in SMARCA4-deficient tumors both in vitro and in vivo $[19,161]$. However, this strategy is questioned by the subset of SMARCA4-inactivated tumors displaying concomitant loss of SMARCA2, namely, SCCOHT and SMARCA4-DTS [108,123]. Moreover, although their precise tissue lineage remains unknown, a minor subsets of lung adenocarcinomas may present a dual loss of SMARCA4 and SMARCA2, and importantly, these patients have a worse prognosis than those with expressing SMARCA4/A2 [162,163]. The next step is to understand whether targeting SMARCA2 with a specific peptide in SMARCA4-deficient cancers will effectively lead to the tumor cell death or if these cancer cells will be able to adapt and resist to such treatments. 
Finally, SWI/SNF subunits could also be used as predictors of therapeutic response. Indeed, in 2008, it was shown that the response of steroid treatment in pediatric acute lymphoblastic leukemia was correlated with the level of expression of $3 \mathrm{SWI} / \mathrm{SNF}$ subunits (SMARCB1, SMARCA4, ARIDIA): lower expression was associated with higher treatment response [164]. Similarly, SMARCE1 expression can be used as a marker of drug response in ovarian cancer and in lung cancer: the sensitivity to cisplatin, doxorubicin, and 5-fluorouracil in ovarian cancer seems to be associated with low SMARCE1 expression [165], whereas low SMARCE1 expression is associated with resistance to $M E T$ and $A L K$ inhibitors in non-small cell lung cancers [166].

\section{E. Concluding remarks}

The SWI/SNF complex subunits are implicated in a wide variety of cellular functions, both in a physiological and pathological context. Unraveling their implication in pathologies should result in the development of new therapeutics targeting mutated SWI/SNF subunits. However, these mutations predominantly result in SWI/SNF complex loss-of-function under pathological conditions, and therapeutic strategies should thus focus on restoring their normal cellular functions. To this end, improving the current understanding of the mechanisms underlying the loss of these subunits and how this loss leads to a pathology, as well as determining which genes are targeted by SWI/SNF or in which pathways these proteins are implicated is of utmost importance.

\section{Acknowledgments}

The authors would like to thank Brigitte Manship for the careful reading of the manuscript and Dr. Mokrane Yaccoub (CHU de Bordeaux) for collecting duct carcinoma samples. 


\section{Funding}

This work was supported by the Institut National de la Santé et de la Recherche Médicale, the Centre Léon Bérard, the Cancer Research Center of Lyon, the Cancéropôle Ile de France and the Institut National du Cancer (grant INCa-PLBIO16-208).

\section{$\underline{\text { Author contributions }}$}

A.O, F.L.L and FT wrote the manuscript.

\section{Conflict of interest}

The authors have no conflicts of interest to disclose. 


\section{$\underline{\text { References }}$}

[1] E.Y. Son, G.R. Crabtree, The role of BAF (mSWI/SNF) complexes in mammalian neural development, Am. J. Med. Genet. C Semin. Med. Genet. 166C (2014) 333-349. doi:10.1002/ajmg.c.31416.

[2] E. Sarnowska, D.M. Gratkowska, S.P. Sacharowski, P. Cwiek, T. Tohge, A.R. Fernie, J.A. Siedlecki, C. Koncz, T.J. Sarnowski, The Role of SWI/SNF Chromatin Remodeling Complexes in Hormone Crosstalk, Trends Plant Sci. 21 (2016) 594-608. doi:10.1016/j.tplants.2016.01.017.

[3] I. Versteege, N. Sévenet, J. Lange, M.-F. Rousseau-Merck, P. Ambros, R. Handgretinger, A. Aurias, O. Delattre, Truncating mutations of hSNF5/INI1 in aggressive paediatric cancer, Nature. 394 (1998) 203-206. doi:10.1038/28212.

[4] A.H. Shain, J.R. Pollack, The spectrum of SWI/SNF mutations, ubiquitous in human cancers, PloS One. 8 (2013) e55119. doi:10.1371/journal.pone.0055119.

[5] C. Kadoch, D.C. Hargreaves, C. Hodges, L. Elias, L. Ho, J. Ranish, G.R. Crabtree, Proteomic and bioinformatic analysis of mammalian SWI/SNF complexes identifies extensive roles in human malignancy, Nat. Genet. 45 (2013) 592-601. doi:10.1038/ng.2628.

[6] K.C. Wiegand, S.P. Shah, O.M. Al-Agha, Y. Zhao, K. Tse, T. Zeng, J. Senz, M.K. McConechy, M.S. Anglesio, S.E. Kalloger, W. Yang, A. Heravi-Moussavi, R. Giuliany, C. Chow, J. Fee, A. Zayed, L. Prentice, N. Melnyk, G. Turashvili, A.D. Delaney, J. Madore, S. Yip, A.W. McPherson, G. Ha, L. Bell, S. Fereday, A. Tam, L. Galletta, P.N. Tonin, D. Provencher, D. Miller, S.J.M. Jones, R.A. Moore, G.B. Morin, A. Oloumi, N. Boyd, S.A. Aparicio, I.-M. Shih, A.-M. Mes-Masson, D.D. Bowtell, M. Hirst, B. Gilks, M.A. Marra, D.G. Huntsman, ARID1A mutations in endometriosisassociated ovarian carcinomas, N. Engl. J. Med. 363 (2010) 1532-1543. doi:10.1056/NEJMoa1008433.

[7] M. Stern, R. Jensen, I. Herskowitz, Five SWI genes are required for expression of the $\mathrm{HO}$ gene in yeast, J. Mol. Biol. 178 (1984) 853-868.

[8] L. Neigeborn, M. Carlson, Genes affecting the regulation of SUC2 gene expression by glucose repression in Saccharomyces cerevisiae, Genetics. 108 (1984) 845-858.

[9] C.L. Peterson, I. Herskowitz, Characterization of the yeast SWI1, SWI2, and SWI3 genes, which encode a global activator of transcription, Cell. 68 (1992) 573-583.

[10] C. Kadoch, G.R. Crabtree, Mammalian SWI/SNF chromatin remodeling complexes and cancer: Mechanistic insights gained from human genomics, Sci. Adv. 1 (2015) e1500447. doi:10.1126/sciadv.1500447.

[11] D. Reisman, S. Glaros, E.A. Thompson, The SWI/SNF complex and cancer, Oncogene. 28 (2009) 1653-1668. doi:10.1038/onc.2009.4.

[12] L. Breeden, K. Nasmyth, Cell cycle control of the yeast $\mathrm{HO}$ gene: cis- and trans-acting regulators, Cell. 48 (1987) 389-397.

[13] J.A. Martens, P.-Y.J. Wu, F. Winston, Regulation of an intergenic transcript controls adjacent gene transcription in Saccharomyces cerevisiae, Genes Dev. 19 (2005) 2695-2704. doi:10.1101/gad.1367605.

[14] T.H. Chi, M. Wan, K. Zhao, I. Taniuchi, L. Chen, D.R. Littman, G.R. Crabtree, Reciprocal regulation of CD4/CD8 expression by SWI/SNF-like BAF complexes, Nature. 418 (2002) 195199. doi:10.1038/nature00876.

[15] W. Wang, J. Côté, Y. Xue, S. Zhou, P.A. Khavari, S.R. Biggar, C. Muchardt, G.V. Kalpana, S.P. Goff, M. Yaniv, J.L. Workman, G.R. Crabtree, Purification and biochemical heterogeneity of the mammalian SWI-SNF complex, EMBO J. 15 (1996) 5370-5382.

[16] F. Winston, C.D. Allis, The bromodomain: a chromatin-targeting module?, Nat. Struct. Biol. 6 (1999) 601-604. doi:10.1038/10640.

[17] A. Dahiya, M.R. Gavin, R.X. Luo, D.C. Dean, Role of the LXCXE binding site in Rb function, Mol. Cell. Biol. 20 (2000) 6799-6805. 
[18] C. Muchardt, M. Yaniv, ATP-dependent chromatin remodelling: SWI/SNF and Co. are on the job, J. Mol. Biol. 293 (1999) 187-198. doi:10.1006/jmbi.1999.2999.

[19] T. Oike, H. Ogiwara, Y. Tominaga, K. Ito, O. Ando, K. Tsuta, T. Mizukami, Y. Shimada, H. Isomura, M. Komachi, K. Furuta, S.-I. Watanabe, T. Nakano, J. Yokota, T. Kohno, A synthetic lethality-based strategy to treat cancers harboring a genetic deficiency in the chromatin remodeling factor BRG1, Cancer Res. 73 (2013) 5508-5518. doi:10.1158/0008-5472.CAN-124593.

[20] G.R. Hoffman, R. Rahal, F. Buxton, K. Xiang, G. McAllister, E. Frias, L. Bagdasarian, J. Huber, A. Lindeman, D. Chen, R. Romero, N. Ramadan, T. Phadke, K. Haas, M. Jaskelioff, B.G. Wilson, M.J. Meyer, V. Saenz-Vash, H. Zhai, V.E. Myer, J.A. Porter, N. Keen, M.E. McLaughlin, C. Mickanin, C.W.M. Roberts, F. Stegmeier, Z. Jagani, Functional epigenetics approach identifies BRM/SMARCA2 as a critical synthetic lethal target in BRG1-deficient cancers, Proc. Natl. Acad. Sci. U. S. A. 111 (2014) 3128-3133. doi:10.1073/pnas.1316793111.

[21] K.C. Helming, X. Wang, C.W.M. Roberts, Vulnerabilities of mutant SWI/SNF complexes in cancer, Cancer Cell. 26 (2014) 309-317. doi:10.1016/j.ccr.2014.07.018.

[22] J. Masliah-Planchon, I. Bièche, J.-M. Guinebretière, F. Bourdeaut, O. Delattre, SWI/SNF chromatin remodeling and human malignancies, Annu. Rev. Pathol. 10 (2015) 145-171. doi:10.1146/annurev-pathol-012414-040445.

[23] Y. Tang, J. Wang, Y. Lian, C. Fan, P. Zhang, Y. Wu, X. Li, F. Xiong, X. Li, G. Li, W. Xiong, Z. Zeng, Linking long non-coding RNAs and SWI/SNF complexes to chromatin remodeling in cancer, Mol. Cancer. 16 (2017) 42. doi:10.1186/s12943-017-0612-0.

[24] Z. Yan, K. Cui, D.M. Murray, C. Ling, Y. Xue, A. Gerstein, R. Parsons, K. Zhao, W. Wang, PBAF chromatin-remodeling complex requires a novel specificity subunit, BAF200, to regulate expression of selective interferon-responsive genes, Genes Dev. 19 (2005) 1662-1667. doi:10.1101/gad.1323805.

[25] M.M. Kasten, C.R. Clapier, B.R. Cairns, SnapShot: Chromatin remodeling: SWI/SNF, Cell. 144 (2011) 310.e1. doi:10.1016/j.cell.2011.01.007.

[26] J.I. Wu, J. Lessard, G.R. Crabtree, Understanding the words of chromatin regulation, Cell. 136 (2009) 200-206. doi:10.1016/j.cell.2009.01.009.

[27] S. Bultman, T. Gebuhr, D. Yee, C. La Mantia, J. Nicholson, A. Gilliam, F. Randazzo, D. Metzger, P. Chambon, G. Crabtree, T. Magnuson, A Brg1 null mutation in the mouse reveals functional differences among mammalian SWI/SNF complexes, Mol. Cell. 6 (2000) 1287-1295.

[28] J.K. Kim, S.O. Huh, H. Choi, K.S. Lee, D. Shin, C. Lee, J.S. Nam, H. Kim, H. Chung, H.W. Lee, S.D. Park, R.H. Seong, Srg3, a mouse homolog of yeast SWI3, is essential for early embryogenesis and involved in brain development, Mol. Cell. Biol. 21 (2001) 7787-7795. doi:10.1128/MCB.21.22.7787-7795.2001.

[29] S. Matsumoto, F. Banine, J. Struve, R. Xing, C. Adams, Y. Liu, D. Metzger, P. Chambon, M.S. Rao, L.S. Sherman, Brg1 is required for murine neural stem cell maintenance and gliogenesis, Dev. Biol. 289 (2006) 372-383. doi:10.1016/j.ydbio.2005.10.044.

[30] A. Klochendler-Yeivin, L. Fiette, J. Barra, C. Muchardt, C. Babinet, M. Yaniv, The murine SNF5/INI1 chromatin remodeling factor is essential for embryonic development and tumor suppression, EMBO Rep. 1 (2000) 500-506. doi:10.1093/embo-reports/kvd129.

[31] X. Gao, P. Tate, P. Hu, R. Tjian, W.C. Skarnes, Z. Wang, ES cell pluripotency and germ-layer formation require the SWI/SNF chromatin remodeling component BAF250a, Proc. Natl. Acad. Sci. U. S. A. 105 (2008) 6656-6661. doi:10.1073/pnas.0801802105.

[32] Z. Yan, Z. Wang, L. Sharova, A.A. Sharov, C. Ling, Y. Piao, K. Aiba, R. Matoba, W. Wang, M.S.H. Ko, BAF250B-associated SWI/SNF chromatin-remodeling complex is required to maintain undifferentiated mouse embryonic stem cells, Stem Cells Dayt. Ohio. 26 (2008) 1155-1165. doi:10.1634/stemcells.2007-0846.

[33] B.L. Kidder, S. Palmer, J.G. Knott, SWI/SNF-Brg1 regulates self-renewal and occupies core pluripotency-related genes in embryonic stem cells, Stem Cells Dayt. Ohio. 27 (2009) 317-328. doi:10.1634/stemcells.2008-0710. 
[34] L. Ho, R. Jothi, J.L. Ronan, K. Cui, K. Zhao, G.R. Crabtree, An embryonic stem cell chromatin remodeling complex, esBAF, is an essential component of the core pluripotency transcriptional network, Proc. Natl. Acad. Sci. U. S. A. 106 (2009) 5187-5191. doi:10.1073/pnas.0812888106.

[35] L. Ho, J.L. Ronan, J. Wu, B.T. Staahl, L. Chen, A. Kuo, J. Lessard, A.I. Nesvizhskii, J. Ranish, G.R. Crabtree, An embryonic stem cell chromatin remodeling complex, esBAF, is essential for embryonic stem cell self-renewal and pluripotency, Proc. Natl. Acad. Sci. U. S. A. 106 (2009) 5181-5186. doi:10.1073/pnas.0812889106.

[36] J. Lessard, J.I. Wu, J.A. Ranish, M. Wan, M.M. Winslow, B.T. Staahl, H. Wu, R. Aebersold, I.A. Graef, G.R. Crabtree, An essential switch in subunit composition of a chromatin remodeling complex during neural development, Neuron. 55 (2007) 201-215. doi:10.1016/j.neuron.2007.06.019.

[37] I. Olave, W. Wang, Y. Xue, A. Kuo, G.R. Crabtree, Identification of a polymorphic, neuronspecific chromatin remodeling complex, Genes Dev. 16 (2002) 2509-2517. doi:10.1101/gad.992102.

[38] J.I. Wu, J. Lessard, I.A. Olave, Z. Qiu, A. Ghosh, I.A. Graef, G.R. Crabtree, Regulation of dendritic development by neuron-specific chromatin remodeling complexes, Neuron. 56 (2007) 94-108. doi:10.1016/j.neuron.2007.08.021.

[39] H. Sawa, H. Kouike, H. Okano, Components of the SWI/SNF complex are required for asymmetric cell division in C. elegans, Mol. Cell. 6 (2000) 617-624.

[40] C. Hansis, G. Barreto, N. Maltry, C. Niehrs, Nuclear reprogramming of human somatic cells by xenopus egg extract requires BRG1, Curr. Biol. CB. 14 (2004) 1475-1480. doi:10.1016/j.cub.2004.08.031.

[41] S. Seo, G.A. Richardson, K.L. Kroll, The SWI/SNF chromatin remodeling protein Brg1 is required for vertebrate neurogenesis and mediates transactivation of Ngn and NeuroD, Dev. Camb. Engl. 132 (2005) 105-115. doi:10.1242/dev.01548.

[42] J.K. Takeuchi, B.G. Bruneau, Directed transdifferentiation of mouse mesoderm to heart tissue by defined factors, Nature. 459 (2009) 708-711. doi:10.1038/nature08039.

[43] W. Cai, S. Albini, K. Wei, E. Willems, R.M. Guzzo, M. Tsuda, L. Giordani, S. Spiering, L. Kurian, G.W. Yeo, P.L. Puri, M. Mercola, Coordinate Nodal and BMP inhibition directs Baf60cdependent cardiomyocyte commitment, Genes Dev. 27 (2013) 2332-2344. doi:10.1101/gad.225144.113.

[44] H. Lickert, J.K. Takeuchi, I. Von Both, J.R. Walls, F. McAuliffe, S.L. Adamson, R.M. Henkelman, J.L. Wrana, J. Rossant, B.G. Bruneau, Baf60c is essential for function of BAF chromatin remodelling complexes in heart development, Nature. 432 (2004) 107-112. doi:10.1038/nature03071.

[45] S. Albini, P. Coutinho, B. Malecova, L. Giordani, A. Savchenko, S.V. Forcales, P.L. Puri, Epigenetic reprogramming of human embryonic stem cells into skeletal muscle cells and generation of contractile myospheres, Cell Rep. 3 (2013) 661-670. doi:10.1016/j.celrep.2013.02.012.

[46] P.C. Toto, P.L. Puri, S. Albini, SWI/SNF-directed stem cell lineage specification: dynamic composition regulates specific stages of skeletal myogenesis, Cell. Mol. Life Sci. CMLS. 73 (2016) 3887-3896. doi:10.1007/s00018-016-2273-3.

[47] H. Lomelí, J. Castillo-Robles, The developmental and pathogenic roles of BAF57, a special subunit of the BAF chromatin-remodeling complex, FEBS Lett. 590 (2016) 1555-1569. doi:10.1002/1873-3468.12201.

[48] P. Zhang, L. Li, Z. Bao, F. Huang, Role of BAF60a/BAF60c in chromatin remodeling and hepatic lipid metabolism, Nutr. Metab. 13 (2016) 30. doi:10.1186/s12986-016-0090-1.

[49] L. Ho, E.L. Miller, J.L. Ronan, W.Q. Ho, R. Jothi, G.R. Crabtree, esBAF facilitates pluripotency by conditioning the genome for LIF/STAT3 signalling and by regulating polycomb function, Nat. Cell Biol. 13 (2011) 903-913. doi:10.1038/ncb2285. 
[50] B.G. Wilson, X. Wang, X. Shen, E.S. McKenna, M.E. Lemieux, Y.-J. Cho, E.C. Koellhoffer, S.L. Pomeroy, S.H. Orkin, C.W.M. Roberts, Epigenetic antagonism between polycomb and SWI/SNF complexes during oncogenic transformation, Cancer Cell. 18 (2010) 316-328. doi:10.1016/j.ccr.2010.09.006.

[51] B.H. Alver, K.H. Kim, P. Lu, X. Wang, H.E. Manchester, W. Wang, J.R. Haswell, P.J. Park, C.W.M. Roberts, The SWI/SNF chromatin remodelling complex is required for maintenance of lineage specific enhancers, Nat. Commun. 8 (2017) 14648. doi:10.1038/ncomms14648.

[52] C. Kadoch, R.T. Williams, J.P. Calarco, E.L. Miller, C.M. Weber, S.M.G. Braun, J.L. Pulice, E.J. Chory, G.R. Crabtree, Dynamics of BAF-Polycomb complex opposition on heterochromatin in normal and oncogenic states, Nat. Genet. 49 (2017) 213-222. doi:10.1038/ng.3734.

[53] J.A. Biegel, G. Kalpana, E.S. Knudsen, R.J. Packer, C.W.M. Roberts, C.J. Thiele, B. Weissman, M. Smith, The role of INI1 and the SWI/SNF complex in the development of rhabdoid tumors: meeting summary from the workshop on childhood atypical teratoid/rhabdoid tumors, Cancer Res. 62 (2002) 323-328.

[54] F. Bourdeaut, S.N. Chi, M.C. Frühwald, Rhabdoid tumors: integrating biological insights with clinical success: a report from the SMARCB1 and Rhabdoid Tumor Symposium, Paris, December 12-14, 2013, Cancer Genet. 207 (2014) 346-351. doi:10.1016/j.cancergen.2014.10.004.

[55] X. Wang, J.R. Haswell, C.W.M. Roberts, Molecular pathways: SWI/SNF (BAF) complexes are frequently mutated in cancer--mechanisms and potential therapeutic insights, Clin. Cancer Res. Off. J. Am. Assoc. Cancer Res. 20 (2014) 21-27. doi:10.1158/1078-0432.CCR-13-0280.

[56] M. Yaniv, Chromatin remodeling: from transcription to cancer, Cancer Genet. 207 (2014) 352357. doi:10.1016/j.cancergen.2014.03.006.

[57] J.I. Geller, J.J. Roth, J.A. Biegel, Biology and Treatment of Rhabdoid Tumor, Crit. Rev. Oncog. 20 (2015) 199-216.

[58] K.H. Kim, C.W.M. Roberts, Mechanisms by which SMARCB1 loss drives rhabdoid tumor growth, Cancer Genet. 207 (2014) 365-372. doi:10.1016/j.cancergen.2014.04.004.

[59] R.S. Lee, C. Stewart, S.L. Carter, L. Ambrogio, K. Cibulskis, C. Sougnez, M.S. Lawrence, D. Auclair, J. Mora, T.R. Golub, J.A. Biegel, G. Getz, C.W.M. Roberts, A remarkably simple genome underlies highly malignant pediatric rhabdoid cancers, J. Clin. Invest. 122 (2012) 2983-2988. doi:10.1172/JCl64400.

[60] B. Vogelstein, N. Papadopoulos, V.E. Velculescu, S. Zhou, L.A. Diaz, K.W. Kinzler, Cancer genome landscapes, Science. 339 (2013) 1546-1558. doi:10.1126/science.1235122.

[61] D.A. Weeks, J.B. Beckwith, G.W. Mierau, D.W. Luckey, Rhabdoid tumor of kidney. A report of 111 cases from the National Wilms' Tumor Study Pathology Center, Am. J. Surg. Pathol. 13 (1989) 439-458.

[62] L.B. Rorke, R.J. Packer, J.A. Biegel, Central nervous system atypical teratoid/rhabdoid tumors of infancy and childhood: definition of an entity, J. Neurosurg. 85 (1996) 56-65. doi:10.3171/jns.1996.85.1.0056.

[63] J.E. Haas, N.F. Palmer, A.G. Weinberg, J.B. Beckwith, Ultrastructure of malignant rhabdoid tumor of the kidney. A distinctive renal tumor of children, Hum. Pathol. 12 (1981) 646-657.

[64] M. Tsuneyoshi, Y. Daimaru, H. Hashimoto, M. Enjoji, Malignant soft tissue neoplasms with the histologic features of renal rhabdoid tumors: an ultrastructural and immunohistochemical study, Hum. Pathol. 16 (1985) 1235-1242.

[65] A.D. Trobaugh-Lotrario, G.E. Tomlinson, M.J. Finegold, L. Gore, J.H. Feusner, Small cell undifferentiated variant of hepatoblastoma: adverse clinical and molecular features similar to rhabdoid tumors, Pediatr. Blood Cancer. 52 (2009) 328-334. doi:10.1002/pbc.21834.

[66] D. Rizzo, P. Fréneaux, H. Brisse, C. Louvrier, D. Lequin, A. Nicolas, D. Ranchère, V. Verkarre, A. Jouvet, C. Dufour, C. Edan, J.-L. Stéphan, D. Orbach, S. Sarnacki, G. Pierron, B. Parfait, M. Peuchmaur, O. Delattre, F. Bourdeaut, SMARCB1 deficiency in tumors from the peripheral nervous system: a link between schwannomas and rhabdoid tumors?, Am. J. Surg. Pathol. 36 (2012) 964-972. doi:10.1097/PAS.0b013e31825798f1. 
[67] T.J. Hollmann, J.L. Hornick, INI1-deficient tumors: diagnostic features and molecular genetics, Am. J. Surg. Pathol. 35 (2011) e47-63. doi:10.1097/PAS.0b013e31822b325b.

[68] S.K. Kia, M.M. Gorski, S. Giannakopoulos, C.P. Verrijzer, SWI/SNF mediates polycomb eviction and epigenetic reprogramming of the INK4b-ARF-INK4a locus, Mol. Cell. Biol. 28 (2008) 34573464. doi:10.1128/MCB.02019-07.

[69] B.G. Wilson, X. Wang, X. Shen, E.S. McKenna, M.E. Lemieux, Y.-J. Cho, E.C. Koellhoffer, S.L. Pomeroy, S.H. Orkin, C.W.M. Roberts, Epigenetic antagonism between polycomb and SWI/SNF complexes during oncogenic transformation, Cancer Cell. 18 (2010) 316-328. doi:10.1016/j.ccr.2010.09.006.

[70] R.T. Nakayama, J.L. Pulice, A.M. Valencia, M.J. McBride, Z.M. McKenzie, M.A. Gillespie, W.L. Ku, M. Teng, K. Cui, R.T. Williams, S.H. Cassel, H. Qing, C.J. Widmer, G.D. Demetri, R.A. Irizarry, K. Zhao, J.A. Ranish, C. Kadoch, SMARCB1 is required for widespread BAF complex-mediated activation of enhancers and bivalent promoters, Nat. Genet. 49 (2017) 1613. doi:10.1038/ng.3958.

[71] B. Brennan, C. Stiller, F. Bourdeaut, Extracranial rhabdoid tumours: what we have learned so far and future directions, Lancet Oncol. 14 (2013) e329-336. doi:10.1016/S14702045(13)70088-3.

[72] R. Schneppenheim, M.C. Frühwald, S. Gesk, M. Hasselblatt, A. Jeibmann, U. Kordes, M. Kreuz, I. Leuschner, J.I. Martin Subero, T. Obser, F. Oyen, I. Vater, R. Siebert, Germline nonsense mutation and somatic inactivation of SMARCA4/BRG1 in a family with rhabdoid tumor predisposition syndrome, Am. J. Hum. Genet. 86 (2010) 279-284. doi:10.1016/j.ajhg.2010.01.013.

[73] I. Christiaans, S.B. Kenter, H.C. Brink, T. a. M. van Os, F. Baas, P. van den Munckhof, A.M.J. Kidd, T.J.M. Hulsebos, Germline SMARCB1 mutation and somatic NF2 mutations in familial multiple meningiomas, J. Med. Genet. 48 (2011) 93-97. doi:10.1136/jmg.2010.082420.

[74] C. Bacci, R. Sestini, A. Provenzano, I. Paganini, I. Mancini, B. Porfirio, R. Vivarelli, M. Genuardi, L. Papi, Schwannomatosis associated with multiple meningiomas due to a familial SMARCB1 mutation, Neurogenetics. 11 (2010) 73-80. doi:10.1007/s10048-009-0204-2.

[75] M. MacCollin, W. Woodfin, D. Kronn, M.P. Short, Schwannomatosis: a clinical and pathologic study, Neurology. 46 (1996) 1072-1079.

[76] T.J.M. Hulsebos, A.S. Plomp, R.A. Wolterman, E.C. Robanus-Maandag, F. Baas, P. Wesseling, Germline mutation of INI1/SMARCB1 in familial schwannomatosis, Am. J. Hum. Genet. 80 (2007) 805-810. doi:10.1086/513207.

[77] M.J. Smith, A.J. Wallace, N.L. Bowers, C.F. Rustad, C.G. Woods, G.D. Leschziner, R.E. Ferner, D.G.R. Evans, Frequency of SMARCB1 mutations in familial and sporadic schwannomatosis, Neurogenetics. 13 (2012) 141-145. doi:10.1007/s10048-012-0319-8.

[78] M.J. Smith, J.A. Walker, Y. Shen, A. Stemmer-Rachamimov, J.F. Gusella, S.R. Plotkin, Expression of SMARCB1 (INI1) mutations in familial schwannomatosis, Hum. Mol. Genet. 21 (2012) 52395245. doi:10.1093/hmg/dds370.

[79] L.M. Sullivan, A.L. Folpe, B.R. Pawel, A.R. Judkins, J.A. Biegel, Epithelioid sarcoma is associated with a high percentage of SMARCB1 deletions, Mod. Pathol. Off. J. U. S. Can. Acad. Pathol. Inc. 26 (2013) 385-392. doi:10.1038/modpathol.2012.175.

[80] L. Chbani, L. Guillou, P. Terrier, A.V. Decouvelaere, F. Grégoire, M.J. Terrier-Lacombe, D. Ranchère, Y.M. Robin, F. Collin, P. Fréneaux, J.-M. Coindre, Epithelioid sarcoma: a clinicopathologic and immunohistochemical analysis of 106 cases from the French sarcoma group, Am. J. Clin. Pathol. 131 (2009) 222-227. doi:10.1309/AJCPU98ABIPVJAIV.

[81] J.L. Hornick, P. Dal Cin, C.D.M. Fletcher, Loss of INI1 expression is characteristic of both conventional and proximal-type epithelioid sarcoma, Am. J. Surg. Pathol. 33 (2009) 542-550. doi:10.1097/PAS.0b013e3181882c54.

[82] P. Modena, E. Lualdi, F. Facchinetti, L. Galli, M.R. Teixeira, S. Pilotti, G. Sozzi, SMARCB1/INI1 tumor suppressor gene is frequently inactivated in epithelioid sarcomas, Cancer Res. 65 (2005) 4012-4019. doi:10.1158/0008-5472.CAN-04-3050. 
[83] J.M. Orrock, J.J. Abbott, L.E. Gibson, A.L. Folpe, INI1 and GLUT-1 expression in epithelioid sarcoma and its cutaneous neoplastic and nonneoplastic mimics, Am. J. Dermatopathol. 31 (2009) 152-156. doi:10.1097/DAD.0b013e31818a5c4f.

[84] J.C. Cordoba, D.M. Parham, W.H. Meyer, E.C. Douglass, A new cytogenetic finding in an epithelioid sarcoma, t(8;22)(q22;q11), Cancer Genet. Cytogenet. 72 (1994) 151-154.

[85] F. Le Loarer, L. Zhang, C.D. Fletcher, A. Ribeiro, S. Singer, A. Italiano, A. Neuville, A. Houlier, F. Chibon, J.-M. Coindre, C.R. Antonescu, Consistent SMARCB1 homozygous deletions in epithelioid sarcoma and in a subset of myoepithelial carcinomas can be reliably detected by FISH in archival material, Genes. Chromosomes Cancer. 53 (2014) 475-486. doi:10.1002/gcc.22159.

[86] L. Guillou, C. Wadden, J.M. Coindre, T. Krausz, C.D. Fletcher, "Proximal-type" epithelioid sarcoma, a distinctive aggressive neoplasm showing rhabdoid features. Clinicopathologic, immunohistochemical, and ultrastructural study of a series, Am. J. Surg. Pathol. 21 (1997) 130-146.

[87] F.M. Enzinger, Epitheloid sarcoma. A sarcoma simulating a granuloma or a carcinoma, Cancer. 26 (1970) 1029-1041.

[88] J. Calderaro, J. Moroch, G. Pierron, F. Pedeutour, C. Grison, P. Maillé, P. Soyeux, A. de la Taille, J. Couturier, A. Vieillefond, M.C. Rousselet, O. Delattre, Y. Allory, SMARCB1/INI1 inactivation in renal medullary carcinoma, Histopathology. 61 (2012) 428-435. doi:10.1111/j.13652559.2012.04228.x.

[89] J.X. Cheng, M. Tretiakova, C. Gong, S. Mandal, T. Krausz, J.B. Taxy, Renal medullary carcinoma: rhabdoid features and the absence of INI1 expression as markers of aggressive behavior, Mod. Pathol. Off. J. U. S. Can. Acad. Pathol. Inc. 21 (2008) 647-652. doi:10.1038/modpathol.2008.44.

[90] J. Calderaro, J. Masliah-Planchon, W. Richer, L. Maillot, P. Maille, L. Mansuy, C. Bastien, A. de la Taille, H. Boussion, C. Charpy, A. Jourdain, C. Bléchet, G. Pierron, D. Gentien, L. Choudat, C. Tournigand, O. Delattre, Y. Allory, F. Bourdeaut, Balanced Translocations Disrupting SMARCB1 Are Hallmark Recurrent Genetic Alterations in Renal Medullary Carcinomas, Eur. Urol. 69 (2016) 1055-1061. doi:10.1016/j.eururo.2015.09.027.

[91] A.A. Hakimi, P.T. Koi, P.M. Milhoua, N.M. Blitman, M. Li, V. Hugec, J.P. Dutcher, R. Ghavamian, Renal medullary carcinoma: the Bronx experience, Urology. 70 (2007) 878-882. doi:10.1016/j.urology.2007.06.1124.

[92] J.R. Srigley, B. Delahunt, Uncommon and recently described renal carcinomas, Mod. Pathol. Off. J. U. S. Can. Acad. Pathol. Inc. 22 Suppl 2 (2009) S2-S23. doi:10.1038/modpathol.2009.70.

[93] C.J. Davis, F.K. Mostofi, I.A. Sesterhenn, Renal medullary carcinoma. The seventh sickle cell nephropathy, Am. J. Surg. Pathol. 19 (1995) 1-11.

[94] M.A. Swartz, J. Karth, D.T. Schneider, R. Rodriguez, J.B. Beckwith, E.J. Perlman, Renal medullary carcinoma: clinical, pathologic, immunohistochemical, and genetic analysis with pathogenetic implications, Urology. 60 (2002) 1083-1089.

[95] A. Agaimy, The expanding family of SMARCB1(INI1)-deficient neoplasia: implications of phenotypic, biological, and molecular heterogeneity, Adv. Anat. Pathol. 21 (2014) 394-410. doi:10.1097/PAP.0000000000000038.

[96] J.A. Bishop, C.R. Antonescu, W.H. Westra, SMARCB1 (INI-1)-deficient carcinomas of the sinonasal tract, Am. J. Surg. Pathol. 38 (2014) 1282-1289. doi:10.1097/PAS.0000000000000285.

[97] A. Agaimy, A. Hartmann, C.R. Antonescu, S.I. Chiosea, S.K. El-Mofty, H. Geddert, H. Iro, J.S. Lewis, B. Märkl, S.E. Mills, M.-O. Riener, T. Robertson, A. Sandison, S. Semrau, R.H.W. Simpson, E. Stelow, W.H. Westra, J.A. Bishop, SMARCB1 (INI-1)-deficient Sinonasal Carcinoma: A Series of 39 Cases Expanding the Morphologic and Clinicopathologic Spectrum of a Recently Described Entity, Am. J. Surg. Pathol. 41 (2017) 458-471. doi:10.1097/PAS.0000000000000797. 
[98] J.L. Llorente, F. López, C. Suárez, M.A. Hermsen, Sinonasal carcinoma: clinical, pathological, genetic and therapeutic advances, Nat. Rev. Clin. Oncol. 11 (2014) 460-472.

doi:10.1038/nrclinonc.2014.97.

[99] J. Laco, M. Chmelařová, H. Vošmiková, K. Sieglová, I. Bubancová, P. Dundr, K. Němejcová, J. Michálek, P. Čelakovský, R. Mottl, I. Sirák, M. Vošmik, A. Ryška, SMARCB1/INI1-deficient sinonasal carcinoma shows methylation of RASSF1 gene: A clinicopathological, immunohistochemical and molecular genetic study of a recently described entity, Pathol. Res. Pract. 213 (2017) 133-142. doi:10.1016/j.prp.2016.10.012.

[100] F. Jamshidi, E. Pleasance, Y. Li, Y. Shen, K. Kasaian, R. Corbett, P. Eirew, A. Lum, P. Pandoh, Y. Zhao, J.E. Schein, R.A. Moore, R. Rassekh, D.G. Huntsman, M. Knowling, H. Lim, D.J. Renouf, S.J.M. Jones, M.A. Marra, T.O. Nielsen, J. Laskin, S. Yip, Diagnostic value of next-generation sequencing in an unusual sphenoid tumor, The Oncologist. 19 (2014) 623-630. doi:10.1634/theoncologist.2013-0390.

[101] M. Hasselblatt, C. Thomas, V. Hovestadt, D. Schrimpf, P. Johann, S. Bens, F. Oyen, S. PeetzDienhart, Y. Crede, A. Wefers, H. Vogel, M.J. Riemenschneider, M. Antonelli, F. Giangaspero, M.C. Bernardo, C. Giannini, N. Ud Din, A. Perry, K. Keyvani, F. van Landeghem, D. Sumerauer, P. Hauser, D. Capper, A. Korshunov, D.T.W. Jones, S.M. Pfister, R. Schneppenheim, R. Siebert, M.C. Frühwald, M. Kool, Poorly differentiated chordoma with SMARCB1/INI1 loss: a distinct molecular entity with dismal prognosis, Acta Neuropathol. (Berl.). 132 (2016) 149-151. doi:10.1007/s00401-016-1574-9.

[102] C. Kadoch, G.R. Crabtree, Reversible disruption of mSWI/SNF (BAF) complexes by the SS18-SSX oncogenic fusion in synovial sarcoma, Cell. 153 (2013) 71-85. doi:10.1016/j.cell.2013.02.036.

[103] J. Clark, P.J. Rocques, A.J. Crew, S. Gill, J. Shipley, A.M. Chan, B.A. Gusterson, C.S. Cooper, Identification of novel genes, SYT and SSX, involved in the $t(X ; 18)(p 11.2 ; q 11.2)$ translocation found in human synovial sarcoma, Nat. Genet. 7 (1994) 502-508. doi:10.1038/ng0894-502.

[104] M.J. McBride, J.L. Pulice, R.T. Nakayama, N. Mashtalir, D.R. Ingram, J.F. Shern, J. Khan, J.L. Hornick, A.J. Lazar, C. Kadoch, Abstract 3875: SSX drives gain-of-function BAF complex chromatin affinity and genomic targeting in synovial sarcoma, Cancer Res. 77 (2017) 38753875. doi:10.1158/1538-7445.AM2017-3875.

[105] T. Kubo, S. Shimose, J. Fujimori, T. Furuta, M. Ochi, Prognostic value of SS18-SSX fusion type in synovial sarcoma; systematic review and meta-analysis, SpringerPlus. 4 (2015) 375. doi:10.1186/s40064-015-1168-3.

[106] S.J. Bultman, J.I. Herschkowitz, V. Godfrey, T.C. Gebuhr, M. Yaniv, C.M. Perou, T. Magnuson, Characterization of mammary tumors from Brg1 heterozygous mice, Oncogene. 27 (2008) 460-468. doi:10.1038/sj.onc.1210664.

[107] L. Witkowski, J. Carrot-Zhang, S. Albrecht, S. Fahiminiya, N. Hamel, E. Tomiak, D. Grynspan, E. Saloustros, J. Nadaf, B. Rivera, C. Gilpin, E. Castellsagué, R. Silva-Smith, F. Plourde, M. Wu, A. Saskin, M. Arseneault, R.G. Karabakhtsian, E.A. Reilly, F.R. Ueland, A. Margiolaki, K. Pavlakis, S.M. Castellino, J. Lamovec, H.J. Mackay, L.M. Roth, T.M. Ulbright, T.A. Bender, V. Georgoulias, M. Longy, A. Berchuck, M. Tischkowitz, I. Nagel, R. Siebert, C.J.R. Stewart, J. Arseneau, W.G. McCluggage, B.A. Clarke, Y. Riazalhosseini, M. Hasselblatt, J. Majewski, W.D. Foulkes, Germline and somatic SMARCA4 mutations characterize small cell carcinoma of the ovary, hypercalcemic type, Nat. Genet. 46 (2014) 438-443. doi:10.1038/ng.2931.

[108] F. Le Loarer, S. Watson, G. Pierron, V.T. de Montpreville, S. Ballet, N. Firmin, A. Auguste, D. Pissaloux, S. Boyault, S. Paindavoine, P.J. Dechelotte, B. Besse, J.M. Vignaud, M. Brevet, E. Fadel, W. Richer, I. Treilleux, J. Masliah-Planchon, M. Devouassoux-Shisheboran, G. Zalcman, Y. Allory, F. Bourdeaut, F. Thivolet-Bejui, D. Ranchere-Vince, N. Girard, S. Lantuejoul, F. Galateau-Sallé, J.M. Coindre, A. Leary, O. Delattre, J.Y. Blay, F. Tirode, SMARCA4 inactivation defines a group of undifferentiated thoracic malignancies transcriptionally related to BAFdeficient sarcomas, Nat. Genet. 47 (2015) 1200-1205. doi:10.1038/ng.3399.

[109] R.H. Young, E. Oliva, R.E. Scully, Small cell carcinoma of the ovary, hypercalcemic type. A clinicopathological analysis of 150 cases, Am. J. Surg. Pathol. 18 (1994) 1102-1116. 
[110] P. Ramos, A.N. Karnezis, W.P.D. Hendricks, Y. Wang, W. Tembe, V.L. Zismann, C. Legendre, W.S. Liang, M.L. Russell, D.W. Craig, J.H. Farley, B.J. Monk, S.P. Anthony, A. Sekulic, H.E. Cunliffe, D.G. Huntsman, J.M. Trent, Loss of the tumor suppressor SMARCA4 in small cell carcinoma of the ovary, hypercalcemic type (SCCOHT), Rare Dis. Austin Tex. 2 (2014) e967148. doi:10.4161/2167549X.2014.967148.

[111] P. Jelinic, J.J. Mueller, N. Olvera, F. Dao, S.N. Scott, R. Shah, J. Gao, N. Schultz, M. Gonen, R.A. Soslow, M.F. Berger, D.A. Levine, Recurrent SMARCA4 mutations in small cell carcinoma of the ovary, Nat. Genet. 46 (2014) 424-426. doi:10.1038/ng.2922.

[112] W.D. Foulkes, B.A. Clarke, M. Hasselblatt, J. Majewski, S. Albrecht, W.G. McCluggage, No small surprise - small cell carcinoma of the ovary, hypercalcaemic type, is a malignant rhabdoid tumour, J. Pathol. 233 (2014) 209-214. doi:10.1002/path.4362.

[113] A. Yoshida, E. Kobayashi, T. Kubo, M. Kodaira, T. Motoi, N. Motoi, K. Yonemori, Y. Ohe, S.-I. Watanabe, A. Kawai, T. Kohno, H. Kishimoto, H. Ichikawa, N. Hiraoka, Clinicopathological and molecular characterization of SMARCA4-deficient thoracic sarcomas with comparison to potentially related entities, Mod. Pathol. Off. J. U. S. Can. Acad. Pathol. Inc. (2017). doi:10.1038/modpathol.2017.11.

[114] C. Love, Z. Sun, D. Jima, G. Li, J. Zhang, R. Miles, K.L. Richards, C.H. Dunphy, W.W.L. Choi, G. Srivastava, P.L. Lugar, D.A. Rizzieri, A.S. Lagoo, L. Bernal-Mizrachi, K.P. Mann, C.R. Flowers, K.N. Naresh, A.M. Evens, A. Chadburn, L.I. Gordon, M.B. Czader, J.I. Gill, E.D. Hsi, A. Greenough, A.B. Moffitt, M. McKinney, A. Banerjee, V. Grubor, S. Levy, D.B. Dunson, S.S. Dave, The genetic landscape of mutations in Burkitt lymphoma, Nat. Genet. 44 (2012) 1321-1325. doi:10.1038/ng.2468.

[115] P.P. Medina, J. Carretero, M.F. Fraga, M. Esteller, D. Sidransky, M. Sanchez-Cespedes, Genetic and epigenetic screening for gene alterations of the chromatin-remodeling factor, SMARCA4/BRG1, in lung tumors, Genes. Chromosomes Cancer. 41 (2004) 170-177. doi:10.1002/gcc.20068.

[116] P.P. Medina, O.A. Romero, T. Kohno, L.M. Montuenga, R. Pio, J. Yokota, M. Sanchez-Cespedes, Frequent BRG1/SMARCA4-inactivating mutations in human lung cancer cell lines, Hum. Mutat. 29 (2008) 617-622. doi:10.1002/humu.20730.

[117] M. Imielinski, A.H. Berger, P.S. Hammerman, B. Hernandez, T.J. Pugh, E. Hodis, J. Cho, J. Suh, M. Capelletti, A. Sivachenko, C. Sougnez, D. Auclair, M.S. Lawrence, P. Stojanov, K. Cibulskis, K. Choi, L. de Waal, T. Sharifnia, A. Brooks, H. Greulich, S. Banerji, T. Zander, D. Seidel, F. Leenders, S. Ansén, C. Ludwig, W. Engel-Riedel, E. Stoelben, J. Wolf, C. Goparju, K. Thompson, W. Winckler, D. Kwiatkowski, B.E. Johnson, P.A. Jänne, V.A. Miller, W. Pao, W.D. Travis, H.I. Pass, S.B. Gabriel, E.S. Lander, R.K. Thomas, L.A. Garraway, G. Getz, M. Meyerson, Mapping the hallmarks of lung adenocarcinoma with massively parallel sequencing, Cell. 150 (2012) 1107-1120. doi:10.1016/j.cell.2012.08.029.

[118] A.M. Dulak, P. Stojanov, S. Peng, M.S. Lawrence, C. Fox, C. Stewart, S. Bandla, Y. Imamura, S.E. Schumacher, E. Shefler, A. McKenna, S.L. Carter, K. Cibulskis, A. Sivachenko, G. Saksena, D. Voet, A.H. Ramos, D. Auclair, K. Thompson, C. Sougnez, R.C. Onofrio, C. Guiducci, R. Beroukhim, Z. Zhou, L. Lin, J. Lin, R. Reddy, A. Chang, R. Landrenau, A. Pennathur, S. Ogino, J.D. Luketich, T.R. Golub, S.B. Gabriel, E.S. Lander, D.G. Beer, T.E. Godfrey, G. Getz, A.J. Bass, Exome and whole-genome sequencing of esophageal adenocarcinoma identifies recurrent driver events and mutational complexity, Nat. Genet. 45 (2013) 478-486. doi:10.1038/ng.2591.

[119] A.S. Ho, K. Kannan, D.M. Roy, L.G.T. Morris, I. Ganly, N. Katabi, D. Ramaswami, L.A. Walsh, S. Eng, J.T. Huse, J. Zhang, I. Dolgalev, K. Huberman, A. Heguy, A. Viale, M. Drobnjak, M.A. Leversha, C.E. Rice, B. Singh, N.G. Iyer, C.R. Leemans, E. Bloemena, R.L. Ferris, R.R. Seethala, B.E. Gross, Y. Liang, R. Sinha, L. Peng, B.J. Raphael, S. Turcan, Y. Gong, N. Schultz, S. Kim, S. Chiosea, J.P. Shah, C. Sander, W. Lee, T.A. Chan, The mutational landscape of adenoid cystic carcinoma, Nat. Genet. 45 (2013) 791-798. doi:10.1038/ng.2643. 
[120] K.J. Brayer, C.A. Frerich, H. Kang, S.A. Ness, Recurrent Fusions in MYB and MYBL1 Define a Common, Transcription Factor-Driven Oncogenic Pathway in Salivary Gland Adenoid Cystic Carcinoma, Cancer Discov. 6 (2016) 176-187. doi:10.1158/2159-8290.CD-15-0859.

[121] A. Agaimy, O. Daum, B. Märkl, I. Lichtmannegger, M. Michal, A. Hartmann, SWI/SNF Complexdeficient Undifferentiated/Rhabdoid Carcinomas of the Gastrointestinal Tract: A Series of 13 Cases Highlighting Mutually Exclusive Loss of SMARCA4 and SMARCA2 and Frequent Coinactivation of SMARCB1 and SMARCA2, Am. J. Surg. Pathol. 40 (2016) 544-553. doi:10.1097/PAS.0000000000000554.

[122] B.G. Wilson, K.C. Helming, X. Wang, Y. Kim, F. Vazquez, Z. Jagani, W.C. Hahn, C.W.M. Roberts, Residual Complexes Containing SMARCA2 (BRM) Underlie the Oncogenic Drive of SMARCA4 (BRG1) Mutation, Mol. Cell. Biol. 34 (2014) 1136-1144. doi:10.1128/MCB.01372-13.

[123] A.N. Karnezis, Y. Wang, P. Ramos, W.P. Hendricks, E. Oliva, E. D’Angelo, J. Prat, M.R. Nucci, T.O. Nielsen, C. Chow, S. Leung, F. Kommoss, S. Kommoss, A. Silva, B.M. Ronnett, J.T. Rabban, D.D. Bowtell, B.E. Weissman, J.M. Trent, C.B. Gilks, D.G. Huntsman, Dual loss of the SWI/SNF complex ATPases SMARCA4/BRG1 and SMARCA2/BRM is highly sensitive and specific for small cell carcinoma of the ovary, hypercalcaemic type, J. Pathol. 238 (2016) 389-400. doi:10.1002/path.4633.

[124] G.R. Hoffman, R. Rahal, F. Buxton, K. Xiang, G. McAllister, E. Frias, L. Bagdasarian, J. Huber, A. Lindeman, D. Chen, R. Romero, N. Ramadan, T. Phadke, K. Haas, M. Jaskelioff, B.G. Wilson, M.J. Meyer, V. Saenz-Vash, H. Zhai, V.E. Myer, J.A. Porter, N. Keen, M.E. McLaughlin, C. Mickanin, C.W.M. Roberts, F. Stegmeier, Z. Jagani, Functional epigenetics approach identifies BRM/SMARCA2 as a critical synthetic lethal target in BRG1-deficient cancers, Proc. Natl. Acad. Sci. U. S. A. 111 (2014) 3128-3133. doi:10.1073/pnas.1316793111.

[125] T. Oike, H. Ogiwara, Y. Tominaga, K. Ito, O. Ando, K. Tsuta, T. Mizukami, Y. Shimada, H. Isomura, M. Komachi, K. Furuta, S.-I. Watanabe, T. Nakano, J. Yokota, T. Kohno, A synthetic lethality-based strategy to treat cancers harboring a genetic deficiency in the chromatin remodeling factor BRG1, Cancer Res. 73 (2013) 5508-5518. doi:10.1158/0008-5472.CAN-124593.

[126] P. Jelinic, B.A. Schlappe, N. Conlon, J. Tseng, N. Olvera, F. Dao, J.J. Mueller, Y. Hussein, R.A. Soslow, D.A. Levine, Concomitant loss of SMARCA2 and SMARCA4 expression in small cell carcinoma of the ovary, hypercalcemic type, Mod. Pathol. 29 (2016) 60-66. doi:10.1038/modpathol.2015.129.

[127] S. Fahiminiya, L. Witkowski, J. Nadaf, J. Carrot-Zhang, C. Goudie, M. Hasselblatt, P. Johann, M. Kool, R.S. Lee, T. Gayden, C.W.M. Roberts, J.A. Biegel, N. Jabado, J. Majewski, W.D. Foulkes, Molecular analyses reveal close similarities between small cell carcinoma of the ovary, hypercalcemic type and atypical teratoid/rhabdoid tumor, Oncotarget. 7 (2016) 1732-1740. doi:10.18632/oncotarget.6459.

[128] J.L. Sauter, R.P. Graham, B.T. Larsen, S.M. Jenkins, A.C. Roden, J.M. Boland, SMARCA4deficient thoracic sarcoma: a distinctive clinicopathological entity with undifferentiated rhabdoid morphology and aggressive behavior, Mod. Pathol. (2017). doi:10.1038/modpathol.2017.61.

[129] X. Wang, R.S. Lee, B.H. Alver, J.R. Haswell, S. Wang, J. Mieczkowski, Y. Drier, S.M. Gillespie, T.C. Archer, J.N. Wu, E.P. Tzvetkov, E.C. Troisi, S.L. Pomeroy, J.A. Biegel, M.Y. Tolstorukov, B.E. Bernstein, P.J. Park, C.W.M. Roberts, SMARCB1-mediated SWI/SNF complex function is essential for enhancer regulation, Nat. Genet. 49 (2017) 289-295. doi:10.1038/ng.3746.

[130] E. Chan-Penebre, K. Armstrong, A. Drew, A.R. Grassian, I. Feldman, S.K. Knutson, K. KuplastBarr, M. Roche, J. Campbell, P. Ho, R.A. Copeland, R. Chesworth, J.J. Smith, H. Keilhack, S.A. Ribich, Selective Killing of SMARCA2- and SMARCA4-deficient Small Cell Carcinoma of the Ovary, Hypercalcemic Type Cells by Inhibition of EZH2: In Vitro and In Vivo Preclinical Models, Mol. Cancer Ther. 16 (2017) 850-860. doi:10.1158/1535-7163.MCT-16-0678.

[131] M.J. Smith, J. O'Sullivan, S.S. Bhaskar, K.D. Hadfield, G. Poke, J. Caird, S. Sharif, D. Eccles, D. Fitzpatrick, D. Rawluk, D. du Plessis, W.G. Newman, D.G. Evans, Loss-of-function mutations in 
SMARCE1 cause an inherited disorder of multiple spinal meningiomas, Nat. Genet. 45 (2013) 295-298. doi:10.1038/ng.2552.

[132] M.J. Smith, A.J. Wallace, C. Bennett, M. Hasselblatt, E. Elert-Dobkowska, L.T. Evans, W.F. Hickey, J. van Hoff, D. Bauer, A. Lee, R.F. Hevner, C. Beetz, D. du Plessis, J.-P. Kilday, W.G. Newman, D.G. Evans, Germline SMARCE1 mutations predispose to both spinal and cranial clear cell meningiomas, J. Pathol. 234 (2014) 436-440. doi:10.1002/path.4427.

[133] E.H. Gerkes, J.M. Fock, W.F.A. den Dunnen, M.J. van Belzen, C.A. van der Lans, E.W. Hoving, I.E. Fakkert, M.J. Smith, D.G. Evans, M.J.W. Olderode-Berends, A heritable form of SMARCE1related meningiomas with important implications for follow-up and family screening, Neurogenetics. 17 (2016) 83-89. doi:10.1007/s10048-015-0472-y.

[134] C. Guichard, G. Amaddeo, S. Imbeaud, Y. Ladeiro, L. Pelletier, I.B. Maad, J. Calderaro, P. Bioulac-Sage, M. Letexier, F. Degos, B. Clément, C. Balabaud, E. Chevet, A. Laurent, G. Couchy, E. Letouzé, F. Calvo, J. Zucman-Rossi, Integrated analysis of somatic mutations and focal copynumber changes identifies key genes and pathways in hepatocellular carcinoma, Nat. Genet. 44 (2012) 694-698. doi:10.1038/ng.2256.

[135] J. Huang, Q. Deng, Q. Wang, K.-Y. Li, J.-H. Dai, N. Li, Z.-D. Zhu, B. Zhou, X.-Y. Liu, R.-F. Liu, Q.-L. Fei, H. Chen, B. Cai, B. Zhou, H.-S. Xiao, L.-X. Qin, Z.-G. Han, Exome sequencing of hepatitis B virus-associated hepatocellular carcinoma, Nat. Genet. 44 (2012) 1117-1121. doi:10.1038/ng.2391.

[136] K. Wang, S.T. Yuen, J. Xu, S.P. Lee, H.H.N. Yan, S.T. Shi, H.C. Siu, S. Deng, K.M. Chu, S. Law, K.H. Chan, A.S.Y. Chan, W.Y. Tsui, S.L. Ho, A.K.W. Chan, J.L.K. Man, V. Foglizzo, M.K. Ng, A.S. Chan, Y.P. Ching, G.H.W. Cheng, T. Xie, J. Fernandez, V.S.W. Li, H. Clevers, P.A. Rejto, M. Mao, S.Y. Leung, Whole-genome sequencing and comprehensive molecular profiling identify new driver mutations in gastric cancer, Nat. Genet. 46 (2014) 573-582. doi:10.1038/ng.2983.

[137] Z.J. Zang, I. Cutcutache, S.L. Poon, S.L. Zhang, J.R. McPherson, J. Tao, V. Rajasegaran, H.L. Heng, N. Deng, A. Gan, K.H. Lim, C.K. Ong, D. Huang, S.Y. Chin, I.B. Tan, C.C.Y. Ng, W. Yu, Y. Wu, M. Lee, J. Wu, D. Poh, W.K. Wan, S.Y. Rha, J. So, M. Salto-Tellez, K.G. Yeoh, W.K. Wong, Y.J. Zhu, P.A. Futreal, B. Pang, Y. Ruan, A.M. Hillmer, D. Bertrand, N. Nagarajan, S. Rozen, B.T. Teh, P. Tan, Exome sequencing of gastric adenocarcinoma identifies recurrent somatic mutations in cell adhesion and chromatin remodeling genes, Nat. Genet. 44 (2012) 570-574. doi:10.1038/ng.2246.

[138] K. Wang, J. Kan, S.T. Yuen, S.T. Shi, K.M. Chu, S. Law, T.L. Chan, Z. Kan, A.S.Y. Chan, W.Y. Tsui, S.P. Lee, S.L. Ho, A.K.W. Chan, G.H.W. Cheng, P.C. Roberts, P.A. Rejto, N.W. Gibson, D.J. Pocalyko, M. Mao, J. Xu, S.Y. Leung, Exome sequencing identifies frequent mutation of ARID1A in molecular subtypes of gastric cancer, Nat. Genet. 43 (2011) 1219-1223. doi:10.1038/ng.982.

[139] Y. Gui, G. Guo, Y. Huang, X. Hu, A. Tang, S. Gao, R. Wu, C. Chen, X. Li, L. Zhou, M. He, Z. Li, X. Sun, W. Jia, J. Chen, S. Yang, F. Zhou, X. Zhao, S. Wan, R. Ye, C. Liang, Z. Liu, P. Huang, C. Liu, H. Jiang, Y. Wang, H. Zheng, L. Sun, X. Liu, Z. Jiang, D. Feng, J. Chen, S. Wu, J. Zou, Z. Zhang, R. Yang, J. Zhao, C. Xu, W. Yin, Z. Guan, J. Ye, H. Zhang, J. Li, K. Kristiansen, M.L. Nickerson, D. Theodorescu, Y. Li, X. Zhang, S. Li, J. Wang, H. Yang, J. Wang, Z. Cai, Frequent mutations of chromatin remodeling genes in transitional cell carcinoma of the bladder, Nat. Genet. 43 (2011) 875-878. doi:10.1038/ng.907.

[140] G. Guo, X. Sun, C. Chen, S. Wu, P. Huang, Z. Li, M. Dean, Y. Huang, W. Jia, Q. Zhou, A. Tang, Z. Yang, X. Li, P. Song, X. Zhao, R. Ye, S. Zhang, Z. Lin, M. Qi, S. Wan, L. Xie, F. Fan, M.L. Nickerson, X. Zou, X. Hu, L. Xing, Z. Lv, H. Mei, S. Gao, C. Liang, Z. Gao, J. Lu, Y. Yu, C. Liu, L. Li, X. Fang, Z. Jiang, J. Yang, C. Li, X. Zhao, J. Chen, F. Zhang, Y. Lai, Z. Lin, F. Zhou, H. Chen, H.C. Chan, S. Tsang, D. Theodorescu, Y. Li, X. Zhang, J. Wang, H. Yang, Y. Gui, J. Wang, Z. Cai, Whole-genome and whole-exome sequencing of bladder cancer identifies frequent alterations in genes involved in sister chromatid cohesion and segregation, Nat. Genet. 45 (2013) 1459-1463. doi:10.1038/ng.2798. 
[141] Y. Jiao, T.M. Pawlik, R.A. Anders, F.M. Selaru, M.M. Streppel, D.J. Lucas, N. Niknafs, V.B. Guthrie, A. Maitra, P. Argani, G.J.A. Offerhaus, J.C. Roa, L.R. Roberts, G.J. Gores, I. Popescu, S.T. Alexandrescu, S. Dima, M. Fassan, M. Simbolo, A. Mafficini, P. Capelli, R.T. Lawlor, A. Ruzzenente, A. Guglielmi, G. Tortora, F. de Braud, A. Scarpa, W. Jarnagin, D. Klimstra, R. Karchin, V.E. Velculescu, R.H. Hruban, B. Vogelstein, K.W. Kinzler, N. Papadopoulos, L.D. Wood, Exome sequencing identifies frequent inactivating mutations in BAP1, ARID1A and PBRM1 in intrahepatic cholangiocarcinomas, Nat. Genet. 45 (2013) 1470-1473. doi:10.1038/ng.2813.

[142] S. Jones, T.-L. Wang, I.-M. Shih, T.-L. Mao, K. Nakayama, R. Roden, R. Glas, D. Slamon, L.A. Diaz, B. Vogelstein, K.W. Kinzler, V.E. Velculescu, N. Papadopoulos, Frequent mutations of chromatin remodeling gene ARID1A in ovarian clear cell carcinoma, Science. 330 (2010) 228231. doi:10.1126/science.1196333.

[143] B.A. Goff, R. Sainz de la Cuesta, H.G. Muntz, D. Fleischhacker, M. Ek, L.W. Rice, N. Nikrui, H.K. Tamimi, J.M. Cain, B.E. Greer, A.F. Fuller, Clear cell carcinoma of the ovary: a distinct histologic type with poor prognosis and resistance to platinum-based chemotherapy in stage III disease, Gynecol. Oncol. 60 (1996) 412-417.

[144] T. Sugiyama, T. Kamura, J. Kigawa, N. Terakawa, Y. Kikuchi, T. Kita, M. Suzuki, I. Sato, K. Taguchi, Clinical characteristics of clear cell carcinoma of the ovary: a distinct histologic type with poor prognosis and resistance to platinum-based chemotherapy, Cancer. 88 (2000) 2584-2589.

[145] D.R. Crotzer, C.C. Sun, R.L. Coleman, J.K. Wolf, C.F. Levenback, D.M. Gershenson, Lack of effective systemic therapy for recurrent clear cell carcinoma of the ovary, Gynecol. Oncol. 105 (2007) 404-408. doi:10.1016/j.ygyno.2006.12.024.

[146] M. Le Gallo, A.J. O'Hara, M.L. Rudd, M.E. Urick, N.F. Hansen, N.J. O'Neil, J.C. Price, S. Zhang, B.M. England, A.K. Godwin, D.C. Sgroi, NIH Intramural Sequencing Center (NISC) Comparative Sequencing Program, P. Hieter, J.C. Mullikin, M.J. Merino, D.W. Bell, Exome sequencing of serous endometrial tumors identifies recurrent somatic mutations in chromatin-remodeling and ubiquitin ligase complex genes, Nat. Genet. 44 (2012) 1310-1315. doi:10.1038/ng.2455.

[147] M. Sausen, R.J. Leary, S. Jones, J. Wu, C.P. Reynolds, X. Liu, A. Blackford, G. Parmigiani, L.A. Diaz, N. Papadopoulos, B. Vogelstein, K.W. Kinzler, V.E. Velculescu, M.D. Hogarty, Integrated genomic analyses identify ARID1A and ARID1B alterations in the childhood cancer neuroblastoma, Nat. Genet. 45 (2013) 12-17. doi:10.1038/ng.2493.

[148] S.S. Kim, M.S. Kim, N.J. Yoo, S.H. Lee, Frameshift mutations of a chromatin-remodeling gene SMARCC2 in gastric and colorectal cancers with microsatellite instability, APMIS Acta Pathol. Microbiol. Immunol. Scand. 121 (2013) 168-169. doi:10.1111/j.1600-0463.2012.02953.x.

[149] R.S. Lee, C.W.M. Roberts, Linking the SWI/SNF complex to prostate cancer, Nat. Genet. 45 (2013) 1268-1269. doi:10.1038/ng.2805.

[150] J.R. Prensner, M.K. Iyer, A. Sahu, I.A. Asangani, Q. Cao, L. Patel, I.A. Vergara, E. Davicioni, N. Erho, M. Ghadessi, R.B. Jenkins, T.J. Triche, R. Malik, R. Bedenis, N. McGregor, T. Ma, W. Chen, S. Han, X. Jing, X. Cao, X. Wang, B. Chandler, W. Yan, J. Siddiqui, L.P. Kunju, S.M.

Dhanasekaran, K.J. Pienta, F.Y. Feng, A.M. Chinnaiyan, The long noncoding RNA SChLAP1 promotes aggressive prostate cancer and antagonizes the SWI/SNF complex, Nat. Genet. 45 (2013) 1392-1398. doi:10.1038/ng.2771.

[151] Y. Wang, L. He, Y. Du, P. Zhu, G. Huang, J. Luo, X. Yan, B. Ye, C. Li, P. Xia, G. Zhang, Y. Tian, R. Chen, Z. Fan, The long noncoding RNA IncTCF7 promotes self-renewal of human liver cancer stem cells through activation of Wnt signaling, Cell Stem Cell. 16 (2015) 413-425. doi:10.1016/j.stem.2015.03.003.

[152] G.M. Euskirchen, R.K. Auerbach, E. Davidov, T.A. Gianoulis, G. Zhong, J. Rozowsky, N. Bhardwaj, M.B. Gerstein, M. Snyder, Diverse Roles and Interactions of the SWI/SNF Chromatin Remodeling Complex Revealed Using Global Approaches, PLOS Genet. 7 (2011) e1002008. doi:10.1371/journal.pgen.1002008. 
[153] S. Balasubramaniam, C.E.S. Comstock, A. Ertel, K.W. Jeong, M.R. Stallcup, S. Addya, P.A. McCue, W.F. Ostrander, M.A. Augello, K.E. Knudsen, Aberrant BAF57 signaling facilitates prometastatic phenotypes, Clin. Cancer Res. Off. J. Am. Assoc. Cancer Res. 19 (2013) 26572667. doi:10.1158/1078-0432.CCR-12-3049.

[154] S. Kagami, T. Kurita, T. Kawagoe, N. Toki, Y. Matsuura, T. Hachisuga, A. Matsuyama, H. Hashimoto, H. Izumi, K. Kohno, Prognostic significance of BAF57 expression in patients with endometrial carcinoma, Histol. Histopathol. 27 (2012) 593-599. doi:10.14670/HH-27.593.

[155] Y. Wang, S.Y. Chen, A.N. Karnezis, S. Colborne, N.D. Santos, J.D. Lang, W.P.D. Hendricks, K.A. Orlando, D. Yap, F. Kommoss, M.B. Bally, G.B. Morin, J.M. Trent, B.E. Weissman, D.G. Huntsman, The histone methyltransferase EZH2 is a therapeutic target in small cell carcinoma of the ovary, hypercalcemic type, J. Pathol. (2017). doi:10.1002/path.4912.

[156] C.M. Fillmore, C. Xu, P.T. Desai, J.M. Berry, S.P. Rowbotham, Y.-J. Lin, H. Zhang, V.E. Marquez, P.S. Hammerman, K.-K. Wong, C.F. Kim, EZH2 inhibition sensitizes BRG1 and EGFR mutant lung tumours to Topoll inhibitors, Nature. 520 (2015) 239-242. doi:10.1038/nature14122.

[157] E.C. Dykhuizen, D.C. Hargreaves, E.L. Miller, K. Cui, A. Korshunov, M. Kool, S. Pfister, Y.-J. Cho, K. Zhao, G.R. Crabtree, BAF complexes facilitate decatenation of DNA by topoisomerase Ila, Nature. 497 (2013) 624-627. doi:10.1038/nature12146.

[158] I. Oruetxebarria, F. Venturini, T. Kekarainen, A. Houweling, L.M.P. Zuijderduijn, A. Mohd-Sarip, R.G.J. Vries, R.C. Hoeben, C.P. Verrijzer, P16INK4a is required for hSNF5 chromatin remodelerinduced cellular senescence in malignant rhabdoid tumor cells, J. Biol. Chem. 279 (2004) 3807-3816. doi:10.1074/jbc.M309333200.

[159] R.G.J. Vries, V. Bezrookove, L.M.P. Zuijderduijn, S.K. Kia, A. Houweling, I. Oruetxebarria, A.K. Raap, C.P. Verrijzer, Cancer-associated mutations in chromatin remodeler hSNF5 promote chromosomal instability by compromising the mitotic checkpoint, Genes Dev. 19 (2005) 665670. doi:10.1101/gad.335805.

[160] B. Geoerger, F. Bourdeaut, S.G. DuBois, M. Fischer, J.I. Geller, N.G. Gottardo, A. Marabelle, A.D.J. Pearson, S. Modak, T. Cash, G.W. Robinson, M. Motta, A. Matano, S.G. Bhansali, J.R. Dobson, S. Parasuraman, S.N. Chi, A Phase I Study of the CDK4/6 Inhibitor Ribociclib (LEE011) in Pediatric Patients with Malignant Rhabdoid Tumors, Neuroblastoma, and Other Solid Tumors, Clin. Cancer Res. Off. J. Am. Assoc. Cancer Res. 23 (2017) 2433-2441. doi:10.1158/1078-0432.CCR-16-2898.

[161] B.G. Wilson, K.C. Helming, X. Wang, Y. Kim, F. Vazquez, Z. Jagani, W.C. Hahn, C.W.M. Roberts, Residual complexes containing SMARCA2 (BRM) underlie the oncogenic drive of SMARCA4 (BRG1) mutation, Mol. Cell. Biol. 34 (2014) 1136-1144. doi:10.1128/MCB.01372-13.

[162] D.N. Reisman, J. Sciarrotta, W. Wang, W.K. Funkhouser, B.E. Weissman, Loss of BRG1/BRM in human lung cancer cell lines and primary lung cancers: correlation with poor prognosis, Cancer Res. 63 (2003) 560-566.

[163] A. Agaimy, F. Fuchs, E.A. Moskalev, H. Sirbu, A. Hartmann, F. Haller, SMARCA4-deficient pulmonary adenocarcinoma: clinicopathological, immunohistochemical, and molecular characteristics of a novel aggressive neoplasm with a consistent TTF1(neg)/CK7(pos)/HepPar1(pos) immunophenotype, Virchows Arch. (2017). doi:10.1007/s00428-017-2148-5.

[164] N. Pottier, W. Yang, M. Assem, J.C. Panetta, D. Pei, S.W. Paugh, C. Cheng, M.L. Den Boer, M.V. Relling, R. Pieters, W.E. Evans, M.H. Cheok, The SWI/SNF chromatin-remodeling complex and glucocorticoid resistance in acute lymphoblastic leukemia, J. Natl. Cancer Inst. 100 (2008) 1792-1803. doi:10.1093/jnci/djn416.

[165] T. Yamaguchi, T. Kurita, K. Nishio, J. Tsukada, T. Hachisuga, Y. Morimoto, Y. Iwai, H. Izumi, Expression of BAF57 in ovarian cancer cells and drug sensitivity, Cancer Sci. 106 (2015) 359366. doi:10.1111/cas.12612.

[166] A.I. Papadakis, C. Sun, T.A. Knijnenburg, Y. Xue, W. Grernrum, M. Hölzel, W. Nijkamp, L.F.A. Wessels, R.L. Beijersbergen, R. Bernards, S. Huang, SMARCE1 suppresses EGFR expression and controls responses to MET and ALK inhibitors in lung cancer, Cell Res. 25 (2015) 445-458. doi:10.1038/cr.2015.16. 
[167] C.W. Roberts, S.A. Galusha, M.E. McMenamin, C.D. Fletcher, S.H. Orkin, Haploinsufficiency of Snf5 (integrase interactor 1 ) predisposes to malignant rhabdoid tumors in mice, Proc. Natl. Acad. Sci. U. S. A. 97 (2000) 13796-13800. doi:10.1073/pnas.250492697.

[168] Q. Liu, S. Galli, R. Srinivasan, W.M. Linehan, M. Tsokos, M.J. Merino, Renal medullary carcinoma: molecular, immunohistochemistry, and morphologic correlation, Am. J. Surg. Pathol. 37 (2013) 368-374. doi:10.1097/PAS.0b013e3182770406.

[169] S.T. Sredni, T. Tomita, Rhabdoid Tumor Predisposition Syndrome, Pediatr. Dev. Pathol. 18 (2015) 49-58. doi:10.2350/14-07-1531-MISC.1.

[170] B.C. Mobley, J.K. McKenney, C.D. Bangs, K. Callahan, K.W. Yeom, R. Schneppenheim, M.G. Hayden, A.M. Cherry, M. Gokden, M.S.B. Edwards, P.G. Fisher, H. Vogel, Loss of SMARCB1/INI1 expression in poorly differentiated chordomas, Acta Neuropathol. (Berl.). 120 (2010) 745-753. doi:10.1007/s00401-010-0767-x.

[171] A. Agaimy, M. Koch, M. Lell, S. Semrau, W. Dudek, D.L. Wachter, A. Knöll, H. Iro, F. Haller, A. Hartmann, SMARCB1(INI1)-deficient sinonasal basaloid carcinoma: a novel member of the expanding family of SMARCB1-deficient neoplasms, Am. J. Surg. Pathol. 38 (2014) 1274-1281. doi:10.1097/PAS.0000000000000236.

[172] P. Ramos, A.N. Karnezis, D.W. Craig, A. Sekulic, M.L. Russell, W.P.D. Hendricks, J.J. Corneveaux, M.T. Barrett, K. Shumansky, Y. Yang, S.P. Shah, L.M. Prentice, M.A. Marra, J. Kiefer, V.L. Zismann, T.A. McEachron, B. Salhia, J. Prat, E. D’Angelo, B.A. Clarke, J.G. Pressey, J.H. Farley, S.P. Anthony, R.B.S. Roden, H.E. Cunliffe, D.G. Huntsman, J.M. Trent, Small cell carcinoma of the ovary, hypercalcemic type, displays frequent inactivating germline and somatic mutations in SMARCA4, Nat. Genet. 46 (2014) 427-429. doi:10.1038/ng.2928.

[173] L. Witkowski, E. Lalonde, J. Zhang, S. Albrecht, N. Hamel, L. Cavallone, S.T. May, J.C. Nicholson, N. Coleman, M.J. Murray, P.F. Tauber, D.G. Huntsman, S. Schönberger, D. Yandell, M. Hasselblatt, M.D. Tischkowitz, J. Majewski, W.D. Foulkes, Familial rhabdoid tumour'avant la lettre'--from pathology review to exome sequencing and back again, J. Pathol. 231 (2013) 3543. doi:10.1002/path.4225.

[174] H. Liang, L.W.T. Cheung, J. Li, Z. Ju, S. Yu, K. Stemke-Hale, T. Dogruluk, Y. Lu, X. Liu, C. Gu, W. Guo, S.E. Scherer, H. Carter, S.N. Westin, M.D. Dyer, R.G.W. Verhaak, F. Zhang, R. Karchin, C.G. Liu, K.H. Lu, R.R. Broaddus, K.L. Scott, B.T. Hennessy, G.B. Mills, Whole-exome sequencing combined with functional genomics reveals novel candidate driver cancer genes in endometrial cancer, Genome Res. 22 (2012) 2120-2129. doi:10.1101/gr.137596.112.

[175] S. Jones, M. Li, D.W. Parsons, X. Zhang, J. Wesseling, P. Kristel, M.K. Schmidt, S. Markowitz, H. Yan, D. Bigner, R.H. Hruban, J.R. Eshleman, C.A. lacobuzio-Donahue, M. Goggins, A. Maitra, S.N. Malek, S. Powell, B. Vogelstein, K.W. Kinzler, V.E. Velculescu, N. Papadopoulos, Somatic mutations in the chromatin remodeling gene ARID1A occur in several tumor types, Hum. Mutat. 33 (2012) 100-103. doi:10.1002/humu.21633.

[176] A. Mamo, L. Cavallone, S. Tuzmen, C. Chabot, C. Ferrario, S. Hassan, H. Edgren, O. Kallioniemi, O. Aleynikova, E. Przybytkowski, K. Malcolm, S. Mousses, P.N. Tonin, M. Basik, An integrated genomic approach identifies ARID1A as a candidate tumor-suppressor gene in breast cancer, Oncogene. 31 (2012) 2090-2100. doi:10.1038/onc.2011.386.

[177] S. Cornen, J. Adelaide, F. Bertucci, P. Finetti, A. Guille, D.J. Birnbaum, D. Birnbaum, M. Chaffanet, Mutations and deletions of ARID1A in breast tumors, Oncogene. 31 (2012) 42554256. doi:10.1038/onc.2011.598.

[178] G. Manceau, E. Letouzé, C. Guichard, A. Didelot, A. Cazes, H. Corté, E. Fabre, K. Pallier, S. Imbeaud, F. Le Pimpec-Barthes, J. Zucman-Rossi, P. Laurent-Puig, H. Blons, Recurrent inactivating mutations of ARID2 in non-small cell lung carcinoma, Int. J. Cancer. 132 (2013) 2217-2221. doi:10.1002/ijc.27900.

[179] W. Xia, S. Nagase, A.G. Montia, S.M. Kalachikov, M. Keniry, T. Su, L. Memeo, H. Hibshoosh, R. Parsons, BAF180 is a critical regulator of p21 induction and a tumor suppressor mutated in breast cancer, Cancer Res. 68 (2008) 1667-1674. doi:10.1158/0008-5472.CAN-07-5276. 
[180] I. Varela, P. Tarpey, K. Raine, D. Huang, C.K. Ong, P. Stephens, H. Davies, D. Jones, M.-L. Lin, J. Teague, G. Bignell, A. Butler, J. Cho, G.L. Dalgliesh, D. Galappaththige, C. Greenman, C. Hardy, M. Jia, C. Latimer, K.W. Lau, J. Marshall, S. McLaren, A. Menzies, L. Mudie, L. Stebbings, D.A. Largaespada, L.F.A. Wessels, S. Richard, R.J. Kahnoski, J. Anema, D.A. Tuveson, P.A. PerezMancera, V. Mustonen, A. Fischer, D.J. Adams, A. Rust, W. Chan-on, C. Subimerb, K. Dykema, K. Furge, P.J. Campbell, B.T. Teh, M.R. Stratton, P.A. Futreal, Exome sequencing identifies frequent mutation of the SWI/SNF complex gene PBRM1 in renal carcinoma, Nature. 469 (2011) 539-542. doi:10.1038/nature09639.

[181] K. De Keersmaecker, P.J. Real, G.D. Gatta, T. Palomero, M.L. Sulis, V. Tosello, P. Van Vlierberghe, K. Barnes, M. Castillo, X. Sole, M. Hadler, J. Lenz, P.D. Aplan, M. Kelliher, B.L. Kee, P.P. Pandolfi, D. Kappes, F. Gounari, H. Petrie, J. Van der Meulen, F. Speleman, E. Paietta, J. Racevskis, P.H. Wiernik, J.M. Rowe, J. Soulier, D. Avran, H. Cavé, N. Dastugue, S. Raimondi, J.P.P. Meijerink, C. Cordon-Cardo, A. Califano, A.A. Ferrando, The TLX1 oncogene drives aneuploidy in T cell transformation, Nat. Med. 16 (2010) 1321-1327. doi:10.1038/nm.2246.

[182] R. Berger, N. Dastugue, M. Busson, J. Van Den Akker, C. Pérot, P. Ballerini, A. Hagemeijer, L. Michaux, C. Charrin, M.P. Pages, F. Mugneret, J. Andrieux, P. Talmant, C. Hélias, L. Mauvieux, M. Lafage-Pochitaloff, M.-J. Mozziconacci, P. Cornillet-Lefebvre, I. Radford, V. Asnafi, C. Bilhou-Nabera, F. Nguyen Khac, C. Léonard, F. Speleman, B. Poppe, C. Bastard, S. Taviaux, B. Quilichini, C. Herens, M.-J. Grégoire, H. Cavé, O.A. Bernard, Groupe Français de Cytogénétique Hématologique (GFCH), $t(5 ; 14) / H O X 11 L 2$-positive T-cell acute lymphoblastic leukemia. A collaborative study of the Groupe Français de Cytogénétique Hématologique (GFCH), Leukemia. 17 (2003) 1851-1857. doi:10.1038/sj.leu.2403061. 


\section{$\underline{\text { Tables }}$}

Table 1: SWI/SNF subunits alterations in cancers. Cancers in which an alteration of SWI/SNF is thought to be driving oncogenesis are indicated in gray.

\begin{tabular}{|c|c|c|c|c|}
\hline Genes & Cancer type & $\%$ & $\begin{array}{c}\text { Genetic alteration in the SWI/SNF } \\
\text { subunits }\end{array}$ & References \\
\hline \multirow{5}{*}{ SMARCB1 } & $\begin{array}{l}\text { Malignant rhabdoid tumor } \\
\text { Epithelioid sarcoma } \\
\text { Renal medullary carcinoma }\end{array}$ & $\begin{array}{c}100 \% \\
80 \%- \\
90 \% \\
100 \%\end{array}$ & $\begin{array}{l}\text { biallelic inactivation } \\
\text { homozygous deletions } \\
\text { loss of heterozygosity }\end{array}$ & $\begin{array}{c}{[3,167]} \\
{[79,80,85]} \\
{[88,168]}\end{array}$ \\
\hline & $\begin{array}{l}\text { Rhabdoid tumor predisposition } \\
\text { syndrome } 1 \\
\text { Familial schwannomatosis }\end{array}$ & $\begin{array}{l}100 \% \\
45 \%\end{array}$ & $\begin{array}{l}\text { heterozygous germline mutation } \\
\text { non-truncating splice-site mutations } \\
\text { and missense mutations in exon } 1\end{array}$ & $\begin{array}{l}{[169]} \\
{[76,78]}\end{array}$ \\
\hline & $\begin{array}{l}\text { Undifferentiated chordomas } \\
\text { with notochordal differentiation } \\
\text { that typically arise in the axial } \\
\text { spine (=atypical chordomas) }\end{array}$ & $100 \%$ & $\begin{array}{l}\text { Heterozygous mutations or deletion, } \\
\text { loss of expression }\end{array}$ & {$[170]$} \\
\hline & Synovial sarcoma & $>95 \%$ & $\begin{array}{l}\text { Expulsion of SMARCB1 from } \\
\text { complex by SS18-SSX }\end{array}$ & [102] \\
\hline & Sinonasal carcinomas & $<10 \%$ & $\begin{array}{l}\text { Homozygous }(\sim 75 \%) \text { or heterozygous } \\
\qquad(\sim 25 \%) \text { deletion }\end{array}$ & {$[96,97,171]$} \\
\hline \multirow{3}{*}{ SMARCA2 } & $\begin{array}{l}\text { Small cell cancer of the ovary, } \\
\text { hypercalcemic type }\end{array}$ & $100 \%$ & no mutation - loss of expression & [123] \\
\hline & $\begin{array}{l}\text { SMARCA4- deficient thoracic } \\
\text { sarcoma }\end{array}$ & $100 \%$ & no mutation - loss of expression & [108] \\
\hline & $\begin{array}{l}\text { undifferentiated carcinomas in } \\
\text { gastrointestinal tract }\end{array}$ & $77 \%$ & unknown & [121] \\
\hline \multirow{3}{*}{ SMARCA4 } & $\begin{array}{l}\text { Ovarian small cell carcinoma of } \\
\text { the hypercalcemic type }\end{array}$ & $91.2 \%$ & biallelic inactivating mutations & $\begin{array}{l}{[107,111,1} \\
72]\end{array}$ \\
\hline & $\begin{array}{l}\text { SMARCA4-deficient thoracic } \\
\text { sarcoma }\end{array}$ & $100 \%$ & $\begin{array}{l}\text { mostly nonsense and frameshift } \\
\text { mutations }\end{array}$ & [108] \\
\hline & $\begin{array}{l}\text { Rhabdoid tumor predisposition } \\
\text { syndrome } 2\end{array}$ & $100 \%$ & heterozygous germline mutation & [173] \\
\hline \multirow[t]{2}{*}{ ARID1A } & Ovarian clear cell carcinomas & $49.1 \%$ & $\begin{array}{l}\text { somatic truncating or missense } \\
\text { mutations }\end{array}$ & {$[6,142]$} \\
\hline & Gastric cancers & $18.7 \%$ & inactivating mutation mostly & [136-138] \\
\hline
\end{tabular}




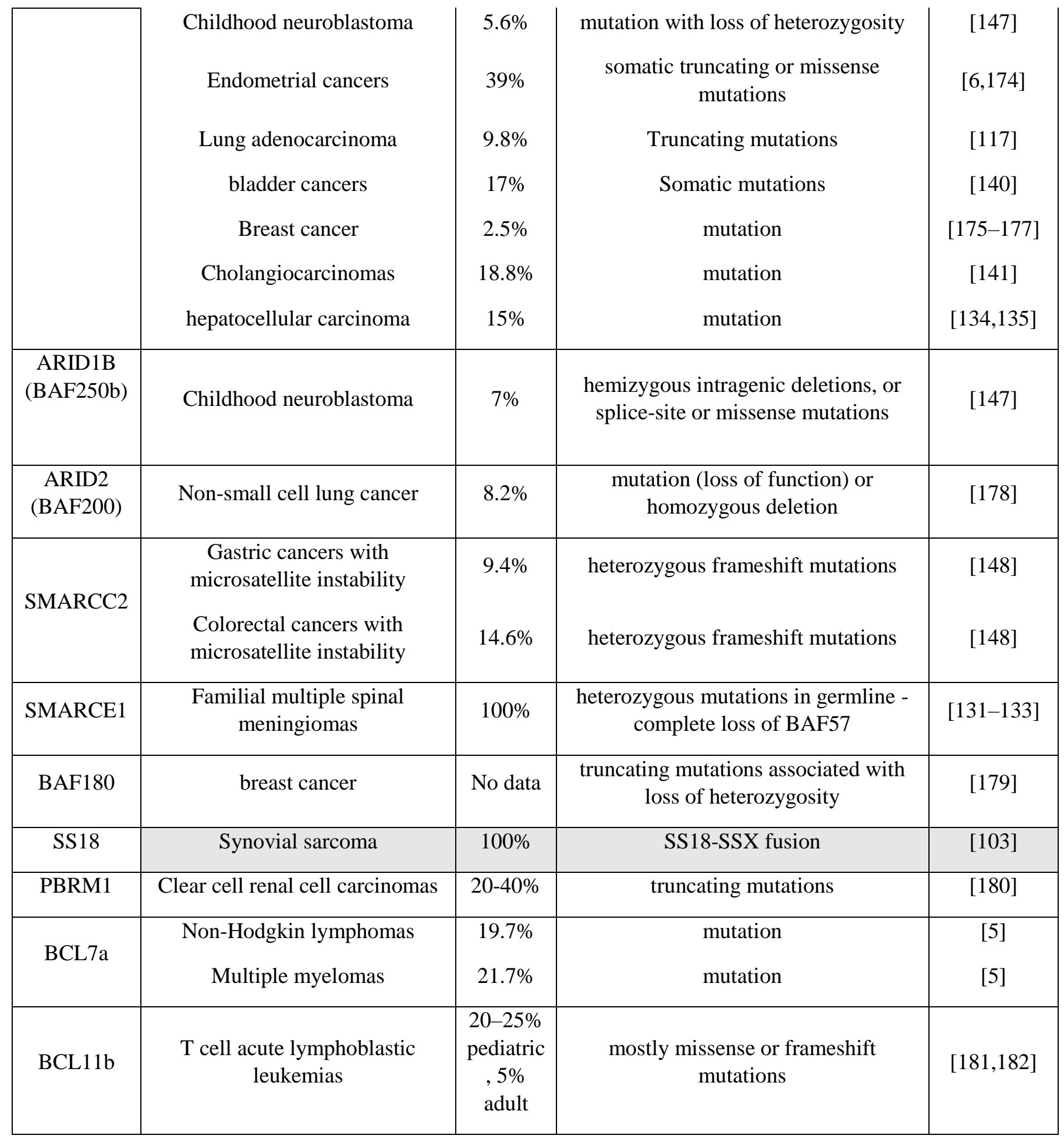


Table 2: Subunits composition of the different SWI/SNF complexes.

The composition of SWI/SNF subunits varies according to cell type and during neuronal development. Some subunits are characteristic of the complex (shown in red) and correspond to the signature subunits.

\begin{tabular}{|c|c|c|c|c|c|}
\hline & \begin{tabular}{|l} 
BAF \\
COMPLEX
\end{tabular} & $\begin{array}{l}\text { PBAF } \\
\text { COMPLEX }\end{array}$ & $\begin{array}{l}\text { ESBAF } \\
\text { COMPLEX }\end{array}$ & $\begin{array}{l}\text { NPBAF } \\
\text { COMPLEX }\end{array}$ & $\begin{array}{l}\text { NBAF } \\
\text { COMPLEX }\end{array}$ \\
\hline $\begin{array}{l}\text { CATALYTIC } \\
\text { SUBUNITS }\end{array}$ & BRM / BRG-1 & BRG-1 & BRG-1 & BRG-1 / BRM & BRG-1 / BRM \\
\hline $\begin{array}{l}\text { CORE } \\
\text { SUBUNITS }\end{array}$ & $\begin{array}{l}\text { BAF47 } \\
\text { BAF155 } \\
\text { BAF170 }\end{array}$ & $\begin{array}{l}\text { BAF47 } \\
\text { BAF155 } \\
\text { BAF170 }\end{array}$ & $\begin{array}{l}\text { BAF47 } \\
\text { BAF155 } \\
-\end{array}$ & $\begin{array}{l}\text { BAF47 } \\
\text { BAF155 } \\
\text { BAF170 }\end{array}$ & $\begin{array}{l}\text { BAF47 } \\
\text { BAF155 } \\
\text { BAF170 }\end{array}$ \\
\hline $\begin{array}{l}\text { ACCESSORY } \\
\text { SUBUNITS }\end{array}$ & $\begin{array}{l}\text { ARID1A / 1B } \\
- \\
\text { BAF57 } \\
\text { BAF60a/ b / c } \\
\text { BAF45a / b / c } \\
\text { BAF53a / b } \\
\text { SS18 } \\
\text { BRD9 } \\
\text { BCL7a / b / c } \\
\text { BCL11a / b }\end{array}$ & $\begin{array}{l}\text { ARID2 } \\
\text { BAF180 } \\
\text { BAF57 } \\
\text { BAF60a/ b / c } \\
\text { BAF45a / b / c } \\
\text { BAF53a / b } \\
- \\
\text { BRD7 } \\
- \\
-\end{array}$ & $\begin{array}{l}\text { ARID1A / } 2 \\
\text { - / BAF180 } \\
\text { BAF57 } \\
\text { BAF60a } \\
\text { BAF45a } \\
\text { BAF53a } \\
\text { SS18 } \\
\text { BRD7 / BRD9 } \\
\text { BCL7a / b / c } \\
\text { BCL11a / b }\end{array}$ & $\begin{array}{l}\text { ARID1A /1B } \\
\text { /2 } \\
\text { - / BAF180 } \\
\text { BAF57 } \\
\text { BAF60a } \\
\text { BAF45a } \\
\text { BAF53a } \\
\text { SS18 } \\
\text { BRD7 / BRD9 } \\
\text { BCL7a / b / c } \\
\text { BCL11a / b }\end{array}$ & $\begin{array}{l}\text { ARID1A /1B } \\
/ 2 \\
\text { - / BAF180 } \\
\text { BAF57 } \\
\text { BAF60a / c } \\
\text { BAF45b / c } \\
\text { BAF53b } \\
\text { CREST } \\
\text { BRD7 / BRD9 } \\
\text { BCL7a / b / c } \\
\text { BCL11a / b }\end{array}$ \\
\hline
\end{tabular}




\section{Figure Legends}

Figure 1: BAF complex assembly

A. Schematic of the subunits composing BAF complexes. The complexes are composed of catalytic subunits (orange), core subunits (blue) and accessory subunits (purple). The subunits are arranged in an arbitrary manner.

B. Schematic of the domains of the catalytic subunits. The catalytic subunits SMARCA2 and SMARCA4 are composed of 6 conserved domains, all of which have a specific function (in purple). The arbitrary size of the domains does not reflect their actual size. 
A

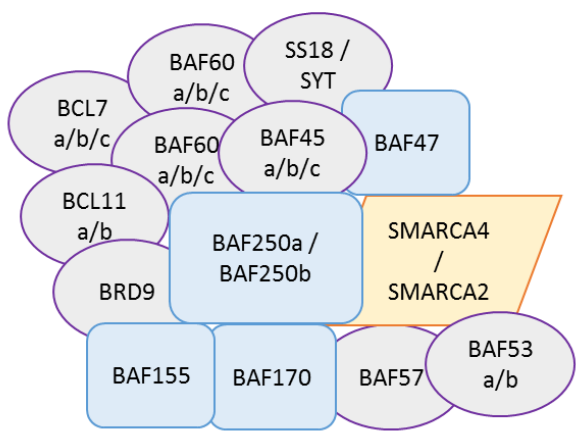

ATPase subunits

Core subunits

Annex subunits

B

\begin{tabular}{|c|c|c|c|c|c|c|}
\hline $\begin{array}{l}\text { Protein } \\
\text { interac }\end{array}$ & $\begin{array}{l}\text { protein } \\
\text { ions }\end{array}$ & Histone interactions & Cata & omain & $\begin{array}{l}\text { RB tumor } \\
\text { suppressor }\end{array}$ & $\begin{array}{l}\text { Acetylated } \\
\text { interaction }\end{array}$ \\
\hline QLQ & Proline-rich & associated & DExDc & HELICC & LxCXE motif & Bromo \\
\hline
\end{tabular}

SMARCA2 / A4

Arnaud et al. Figure 1 
